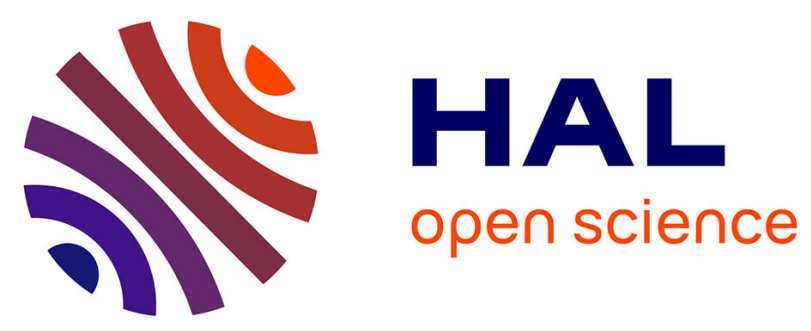

\title{
Phenol and benzenoid alcohols separation from aqueous stream using cloud point extraction: Scaling-up of the process in a mixer-settler
}

Houaria Benkhedja, Jean-Paul Canselier, Christophe Gourdon, B. Haddou

\section{- To cite this version:}

Houaria Benkhedja, Jean-Paul Canselier, Christophe Gourdon, B. Haddou. Phenol and benzenoid alcohols separation from aqueous stream using cloud point extraction: Scaling-up of the process in a mixer-settler. Journal of Water Process Engineering, 2017, 18, pp.202-212. 10.1016/j.jwpe.2017.06.016 . hal-01882466

\section{HAL Id: hal-01882466 https://hal.science/hal-01882466}

Submitted on 27 Sep 2018

HAL is a multi-disciplinary open access archive for the deposit and dissemination of scientific research documents, whether they are published or not. The documents may come from teaching and research institutions in France or abroad, or from public or private research centers.
L'archive ouverte pluridisciplinaire HAL, est destinée au dépôt et à la diffusion de documents scientifiques de niveau recherche, publiés ou non, émanant des établissements d'enseignement et de recherche français ou étrangers, des laboratoires publics ou privés. 


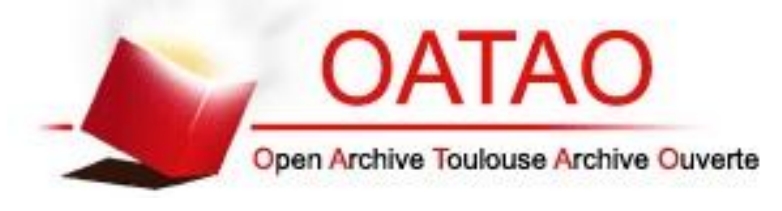

Open Archive Toulouse Archive Ouverte

OATAO is an open access repository that collects the work of Toulouse researchers and makes it freely available over the web where possible

This is an author's version published in: http://oatao.univ-toulouse.fr/20425

Official URL: https://doi.org/10.1016/j.jwpe.2017.06.016

\section{To cite this version:}

Benkhedja, Houaria $\leftrightarrows$ and Canselier, Jean-Paul $\leftrightarrows$ and Gourdon, Christophe Haddou, B. Phenol and benzenoid alcohols separation from aqueous stream using cloud point extraction: Scaling-up of the process in a mixer-settler. (2017) Journal of Water Process Engineering, 18. 202-212. ISSN 2214-7144

Any correspondence concerning this service should be sent to the repository administrator: tech-oatao@listes-diff.inp-toulouse.fr 


\title{
Phenol and benzenoid alcohols separation from aqueous stream using cloud point extraction: Scaling-up of the process in a mixer-settler
}

\author{
H. Benkhedja ${ }^{\mathrm{a}, \mathrm{b}}$, J.P Canselier ${ }^{\mathrm{a}}$, C. Gourdon ${ }^{\mathrm{a}}$, B. Haddou ${ }^{\mathrm{b}, *}$ \\ ${ }^{a}$ Laboratoire de Génie Chimique, UMR 5503, BP 84234, Campus INP-ENSIACET, No 4 Allée Emile Monso, Toulouse cedex 4, France \\ b U. S. T. Oran, Faculté de chimie, Département de génie Chimique, Laboratoire de Physico-Chimie des Matériaux, BP 1505, M'Nouar, Oran, Algérie
}

\begin{abstract}
A B S T R A C T
In the present work, the cloud point extraction (CPE) of three organic pollutants (phenol,benzyl alcohol and 1phenylethanol) with aqueous solutions of biodegradable alkoxylated nonionic surfactants (TERGITOL 15-S-7 and SIMULSOL NW342), is investigated. First, the partial phase diagrams of the water-surfactant binary systems are established. Then, the effects of organic pollutants and sodium chloride on the cloud point $\left(T_{c}\right)$ are determined. Extraction efficiency is evaluated by the following responses: percentage of solute extracted, E (\%), residual concentrations of solute and surfactant in dilute phase $\left(\mathrm{X}_{\mathrm{s}, \mathrm{w}}\right.$, and $\mathrm{X}_{\mathrm{t}, \mathrm{w}}$, respectively) and volume fraction of coacervate at equilibrium $\left(\phi_{c}\right)$. Three-dimensional empirical correlations are used for fitting the experimental results. The comparison between experimental and calculated values allows model parameter identification. Based on these data, CPE was implemented in a continuous mixer-settler device. The feasibility of a multi-stage crossflow process for the purification of samples containing phenol using SIMULSOL NW342 was tested. Six stages were required to reduce the pollutant concentration below the allowed level $(0.3 \mathrm{ppm})$, which proves the efficiency of CPE in the treatment of wastewaters.
\end{abstract}

\section{Introduction}

From the wide variety of organic pollutants, phenol, benzyl alcohol and1-phenylethanol were chosen for this study. Phenol is considered as one of the major water pollutants. Even at very low doses, it is still very dangerous because of its persistence, toxicity, ecotoxicity and bioaccumulation [1-5]. The Environmental Protection Agency (EPA) and the French legislation limit its allowedconcentration in surface waters to $0.3 \mathrm{mg} / \mathrm{L}[6,7]$. For phenol removal, solvent extraction, adsorption, but also ion exchange, polymerization, electro-coagulation, membranebased separations and biological methods have been found effective $[1,4,8-10]$. In soap, perfume and flavor industries, benzyl alcohol is employed as such in bar soap fragrances and in the form of its esters. It is also used in the polymer industry and in the manufacture of car tires. Its photocatalytic degradation has been investigated [11]. 1-Phenylethanol is mainly a coproduct of the oxidation step of ethylbenzene, whose hydroperoxide is used to convert propylene to its oxide. It is then valorized through dehydration to styrene. It can be burnt in a chemical incinerator equipped with a post combustion and epuration system [12].

The laws and regulations on wastewater treatment are becoming increasingly strict. Therefore, there is a strong trend to develop efficient methods for the removal and/or recovery of toxic species in the environment [13]. Among others, Cloud Point Extraction (CPE) appears to be a relatively simple and ecologically safe technique. In fact, the aqueous solutions of most polyethoxylated nonionic surfactants become cloudy and start to separate into two phases, coacervate and dilute phase, as soon as temperature rises above their cloud point, $T_{c}$ [14]. This phenomenon is the basis of the CPE process [15-20]. This latter avoids the use of an organic solvent, produces small sludge volume and requires low energy consumption. This process is very efficient for treating water containing various contaminants including dissolved or dispersed organic matter [21-40]. This method of water purification was also applied to the extraction of metal ions using diverse appropriate chelates [15,41-44] and without chelates [45-49]. Associated to the cloud point value, the main factors in surfactant selection are its biodegradability, toxicity and ecotoxicity. The use of CPE offers an interesting alternative to conventional extraction systems. This technique allows moving toward Green Chemistry. Many advantages were claimed to CPE compared with conventional liquid-liquid extraction: $\mathrm{CPE}$ is an efficient and selective process that works continuously, saves energy and can be scaled up [50-54]. On the basis of this finding, the batch CPE of phenol, benzyl alcohol and 1-phenylethanol from aqueous solution was investigated in the present work. The effects of 


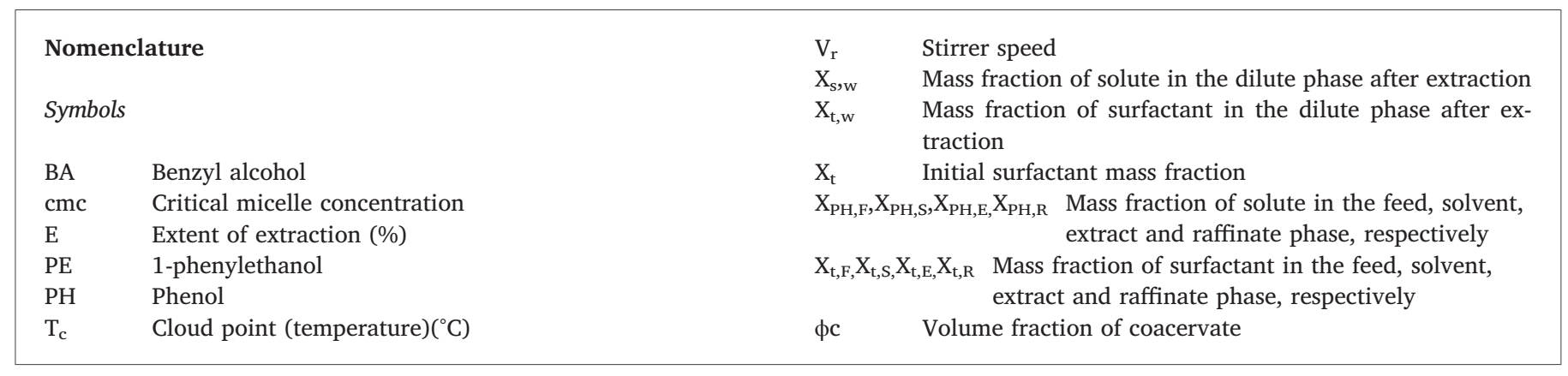

temperature, surfactant concentration and decantation time on solute extraction extent were also studied. For this purpose, two polyalkoxylated nonionic surfactants were used: TERGITOL 15-S-7 and SIMULSOL NW342. The initial pollutant concentration used in water was 0.2 wt.\%. Using these data, the continuous multi-stage crossflow cloud point extraction was implemented in a mixer-settler. As a model system, phenol was extracted using SIMULSOL NW342. The mixer-settler can be easily arranged in battery for counter-current multi-stage process. Each mixer-settler couple can be considered as a theoretical stage. This equipment offers the advantage to operate with highly unequal phase fractions. This technology is able to operate with high flow rates, and can be useful for wastewater treatment.

\section{Materials and methods}

\subsection{Chemical species}

The nonionic surfactants used in this work were obtained from Oxoalcohol alkoxylation: SIMULSOL NW342 $(\mathrm{cmc}=1.52 \mathrm{mmol} / \mathrm{L}$ at $15{ }^{\circ} \mathrm{C}$ ), kindly provided by SEPPIC (Castres, France) and TERGITOL 15$\mathrm{S}-7\left(\mathrm{cmc}=1.22 \mathrm{mmol} / \mathrm{L}\right.$ at $\left.20^{\circ} \mathrm{C}\right)$, a Dow Chemical specialty purchased from Aldrich, are mixtures of primary and secondary alcohol alkoxylates with the alcohol group located at various positions along the carbon chain. Phenol, benzyl alcohol and 1-phenylethanol were purchased from Aldrich and sodium chloride from VWR. The formulas and some properties of the species used in this work are listed in Table 1. Deionized water was used in all cases except for the HPLC analyses, carried out with ultrapure water.

\subsection{Methods}

\subsubsection{Cloud point measurements}

Cloud point measurements were carried out using a Mettler FP 900 apparatus. It consists of a FP90 control and operating unit, and a FP81C measuring cell dedicated to cloud point measurements. The cell temperature was measured with a Pt100 sensor; light transmission was measured continuously, while the cell temperature was increasing linearly according to the chosen heating rate. The cloud point corresponds to the temperature at which the limpid phase becomes cloudy, inducing a light transmission decrease.

\subsubsection{Experimental conditions}

For batch extraction tests, $30 \mathrm{~mL}$ of solution, containing the surfactant (at concentrations from 2 to $10 \mathrm{wt} . \%$ ) and the solute (0.2 wt.\%) in demineralized water, were poured into graduated cylinders and heated in a precision oven and kept during $24 \mathrm{~h}$ to reach equilibrium. The volumes of both phases (coacervate and dilute) were measured.

The dilute phase was analyzed. The residual pollutant and surfactant concentrations were determined by reversed-phase high-performance liquid chromatography: for the solutes, the conditions were as follows: column RP18 (ODS), $95 \mathrm{bar}$, mobile phase $\mathrm{H}_{2} \mathrm{O} / \mathrm{CH}_{3} \mathrm{CN}$ / $\mathrm{CH}_{3} \mathrm{OH}, 42.5 / 50 / 7.5(\mathrm{v} / \mathrm{v})$, flowrate $1 \mathrm{~mL} / \mathrm{min}$.; $\lambda=260 \mathrm{~nm}$; $\mathrm{t}=25{ }^{\circ} \mathrm{C}$. The conditions were slightly different for the surfactant: mobile phase $\mathrm{H}_{2} \mathrm{O} / \mathrm{CH}_{3} \mathrm{CN} / \mathrm{CH}_{3} \mathrm{OH}, 7.5 / 60 / 32.5$ (v/v). The sensitivity of the evaporative light-scattering detector (DDL 31, EUROSEP Instruments) was optimized by the control of the air flowrate in the atomizer (relative pressure: $1 \mathrm{bar}$ ), the temperature of the evaporator $\left(55^{\circ} \mathrm{C}\right)$ and the gain of the photomultiplier $(400 \mathrm{mV})$ [59-61].

The total capacity of the mixer-settler (Fig. 1); temptatively used by our research group in a previous work [21], was $9.5 \mathrm{~L}$. However, the occupied volume was $7 \mathrm{~L}$. The stirrer diameter was $6.5 \mathrm{~cm}$ and the mixing tank diameter was $8.5 \mathrm{~cm}$. The cylindrical settler was $98 \mathrm{~cm}$ length and $10 \mathrm{~cm}$ diameter; the stirring speed could vary from 0 to $900 \mathrm{rpm}$. For the ternary water/Simulsol NW342/phenol system, the equipment was operated with equal volumes of the feed solution $\mathrm{F}$ ( $0.4 \mathrm{wt} . \%$ phenol) and the solvent S ( $8 \mathrm{wt} . \%$ surfactant); the mixture was maintained at $30^{\circ} \mathrm{C}$.

\subsubsection{Extraction parameters}

In order to find the optimal conditions of the two variables: wt.\% surfactant $\left(\mathrm{X}_{\mathrm{t}}\right)$, and temperature (T), allowing to obtain the best possible extraction results, we have worked out the best compromise between the four "responses", $\mathrm{Y}\left(\mathrm{E}, \mathrm{X}_{\mathrm{s}, \mathrm{w}}, \mathrm{X}_{\mathrm{t}, \mathrm{w}}\right.$ and $\left.\phi_{\mathrm{c}}\right)$, defined as follows:

- The extraction yield E (\%):

$\mathrm{E}(\%)=\frac{m_{s(i n)}-m_{\mathrm{s}(\mathrm{w})}}{m_{s(i n)}} \times 100$

Where $\mathrm{m}_{\mathrm{S}(\mathrm{in})}$ and $\mathrm{m}_{\mathrm{S}(\mathrm{w})}$ represent the mass of the solute in the initial solution and in the dilute phase, respectively.

- The volume fraction of coacervate ${ }_{c}$, i.e. the ratio of the volume of the coacervate, $\mathrm{V}_{\mathrm{C}}$, to the total volume $\left(\mathrm{V}_{\mathrm{C}}+\mathrm{V}_{\mathrm{w}}\right), \mathrm{V}_{\mathrm{w}}$ being the volume of the dilute phase:

$\phi_{\mathrm{c}}=\frac{V c}{V c+V w}$

- The weight percentage of solute in the dilute phase:

$\mathrm{X}_{\mathrm{s}, \mathrm{w}}(\%)=\frac{m_{s(w)}}{m_{w}} \times 100$

with $m_{w}$ : mass of dilute phase,

The weight percentage of surfactant in the dilute phase:

Table 1

Chemicals: formulas and properties.

\begin{tabular}{|c|c|c|c|}
\hline Name (abbreviation) & Formula & $\begin{array}{l}\text { Aqueous } \\
\text { solubility at } \\
25{ }^{\circ} \mathrm{C}(\mathrm{g} / \mathrm{L})\end{array}$ & $\begin{array}{l}\log P \\
{[58]}\end{array}$ \\
\hline $\begin{array}{l}\text { SIMULSOL NW342 (Oxo- } \\
\qquad \mathrm{C}_{10} \mathrm{E}_{3} \mathrm{P}_{4} \mathrm{E}_{2} \text { ) }\end{array}$ & $\begin{array}{l}\mathrm{C}_{10} \mathrm{H}_{21}-\left(\mathrm{OCH}_{2}-\mathrm{CH}_{2}\right)_{3^{-}} \\
\left(\mathrm{O}-\mathrm{CH}_{2} \mathrm{CH}\left(\mathrm{CH}_{3}\right)\right)_{4^{-}} \\
\left(\mathrm{OCH}_{2}-\mathrm{CH}_{2}\right)_{2}-\mathrm{OH}\end{array}$ & & \\
\hline $\begin{array}{l}\text { TERGITOL 15-S-7 } \\
\qquad\left(\mathrm{C}_{\left.11^{-1}{ }^{-15} \mathrm{E}_{7.3}\right)}\right.\end{array}$ & $\begin{array}{l}\mathrm{C}_{15} \mathrm{H}_{31}-\left(\mathrm{O}-\mathrm{CH}_{2}-\mathrm{CH}_{2}\right)_{7.3^{-}} \\
\mathrm{OH}\end{array}$ & & \\
\hline Phenol (PH) & $\mathrm{C}_{6} \mathrm{H}_{5} \mathrm{OH}$ & $82.8[55]$ & 1.5 \\
\hline Benzyl alcohol (AB) & $\mathrm{C}_{6} \mathrm{H}_{5} \mathrm{CH}_{2} \mathrm{OH}$ & $40[56]$ & 1.05 \\
\hline 1-Phenylethanol (PE) & $\mathrm{C}_{6} \mathrm{H}_{5} \mathrm{CH}\left(\mathrm{CH}_{3}\right) \mathrm{OH}$ & $\begin{array}{l}20\left(\text { at } 20^{\circ} \mathrm{C}\right) \\
{[57]}\end{array}$ & 1.42 \\
\hline
\end{tabular}




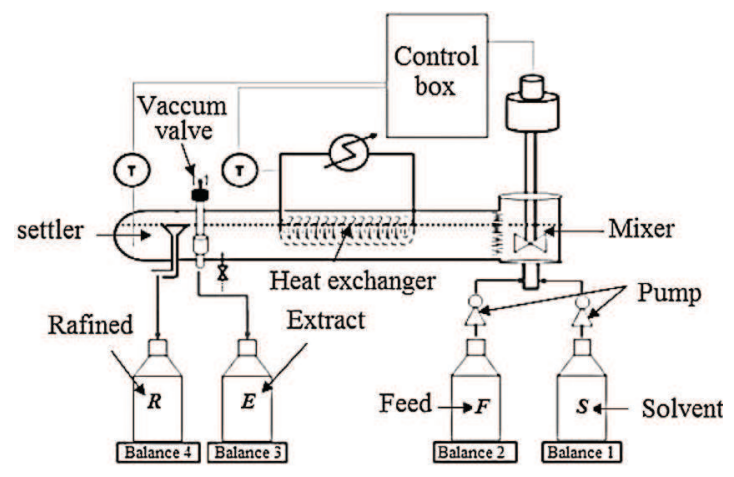

Fig. 1. Mixer-settler device.

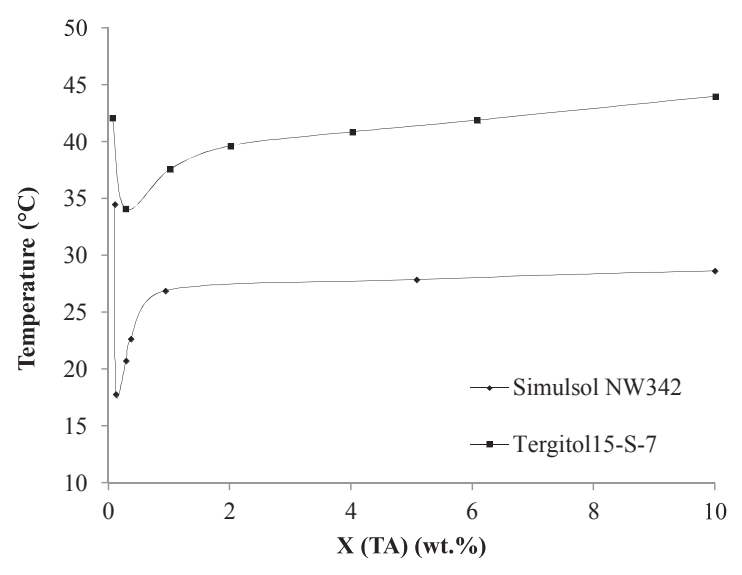

Fig. 2. The cloud point of nonionic surfactants.

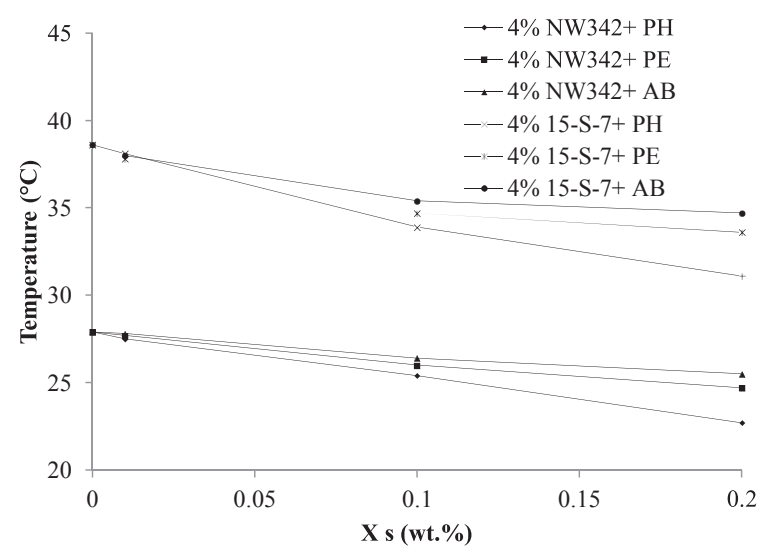

Fig. 3. Effect of solutes on the cloud point of SIMULSOL NW342 and TERGITOL 15-S-7.

$X_{t, w}(\%)=\frac{m_{t(w)}}{m_{w}} \times 100$

with $m_{v w}$ : mass of surfactant in dilute phase.

Those four criteria can be sufficient to evaluate the performances of a single contact extraction.

\section{Modeling of results}

By using the two variables: wt.\% surfactant $\left(\mathrm{X}_{\mathrm{t}}\right)$, and temperature (T), the extraction results of the three solutes at $0.2 \mathrm{wt} \%$ by the two surfactants (TERGITOL 15-S-7 and SIMULSOL NW342) were expressed by four responses (Y): percentage of extracted solute (E), residual concentrations of solute and surfactant in dilute phase $X_{s, w}$, and $X_{t, w}$, respectively, and coacervate volume fraction at equilibrium $\left(\phi_{\mathrm{c}}\right)$. For each parameter determined by considering central composite designs, the results were analyzed using an empirical fitting method. [36,62,63].

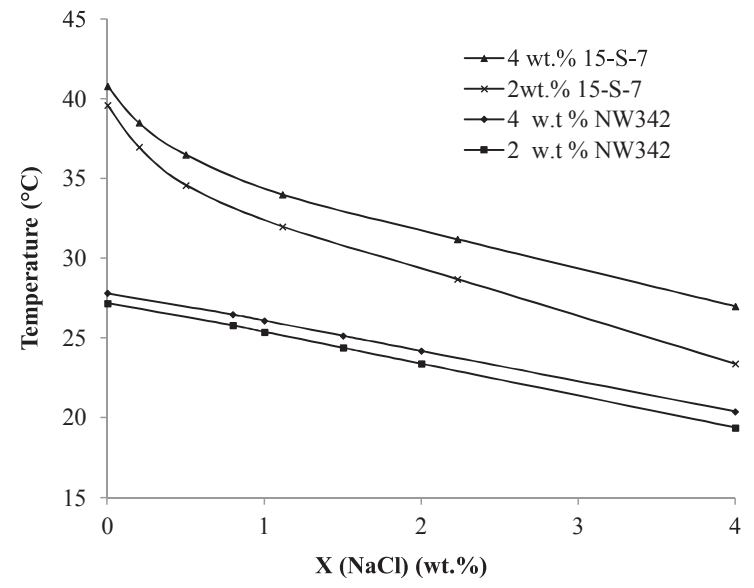

Fig. 4. Effect of $\mathrm{NaCl}$ on the cloud points of SIMULSOL NW342 and TERGITOL 15-S-7.

The experimental values could be used to determine the quadratic polynomial model constants, which were adjusted. The models were checked by plotting computed data against experimental results. The nonlinear system formed by the equations:

$\mathrm{Y}=\mathrm{a}_{0}+\mathrm{a}_{1} \mathrm{X}_{\mathrm{t}}+\mathrm{a}_{2} \mathrm{~T}+\mathrm{a}_{12} \mathrm{X}_{\mathrm{t}} \mathrm{T}+\mathrm{a}_{11} \mathrm{X}_{\mathrm{t}}^{2}+\mathrm{a}_{22} \mathrm{~T}^{2}$

was solved to give the slope and the regression coefficient $\left(R^{2}\right)$ closest to unity. Even if the quadratic equations for $\mathrm{E}, \mathrm{X}_{\mathrm{s}, \mathrm{w}}, \mathrm{X}_{\mathrm{t} . \mathrm{w}}$ and $\phi_{\mathrm{c}}$ allow to obtain a good correlation with the experimental values, one has to keep in mind that the model validity is restricted to the field of study and a physical significance cannot be given to the portion of horizontal planes corresponding to the maximal values of the response.

Coefficient identification and data treatment of response surfaces were carried out using the STATISTICA software (8.0.360.0).

\section{Results and discussion}

\subsection{Binary and pseudo-binary phase diagrams}

Before the extraction test, it is necessary to plot the phase diagrams of the following systems: water/surfactant and water/surfactant with a fixed solute content (pseudo-binary systems) as a function of temperature. One can notice in Fig. 2 that the cloud points of TERGITOL are higher than those of SIMULSOL NW342. Thus, the critical temperature of this latter $\left(\mathrm{t}_{\mathrm{c}}=17^{\circ} \mathrm{C}\right)$ is lower than the ambient one, while that of TERGITOL $15-\mathrm{S}-7$ is above $34{ }^{\circ} \mathrm{C}$. This might have been difficult to predict, since the surfactants do not belong to the same series, and TERGITOL 15-S-7 possesses longer hydrophobic tail and hydrophilic head at the same time. Thus, the effect of the four propylene oxide groups of SIMULSOL NW342 prevails over the shortening of the aliphatic chain The cloud-point curves are more sensitive to surfactant concentration in a narrow range of lower values.

\subsubsection{Effect of organic solutes}

The effect of the three organic solutes phenol, benzyl alcohol and 1phenylethanol, in the range $0-2 \mathrm{~g} / \mathrm{L}$, on the cloud points of SIMULSOL NW342 and TERGITOL 15-S-7 has been investigated, as an example of solute effect. For $X_{t}=4 \mathrm{wt} . \%$, the results are shown in Fig. 3. One can notice that very small concentrations of the three additives have no effect on the cloud point. However, at higher concentration, those compounds lower the cloud points of both nonionic surfactants. In each case, the trend is similar: phenol shows the strongest effect, whilst benzyl alcohol the lowest. Besides, the effect of solutes is relatively higher at lower surfactant concentration.

The influence of solutes on the cloud point is governed by their hydrophobic affinity, namely their octanol-water partition coefficients, expressed as $\log$ P. (Table 1). Although phenol is more soluble in water 


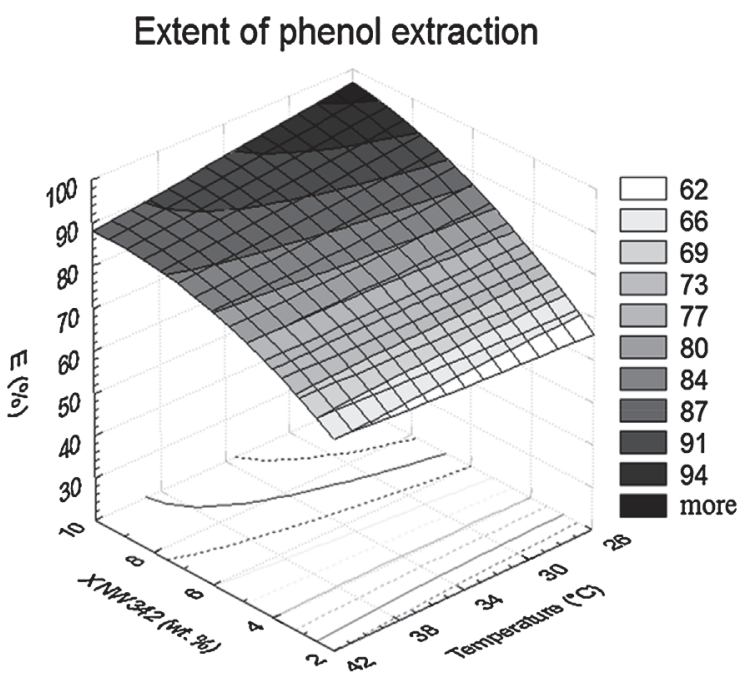

Extent of Benzyl alcohol extraction

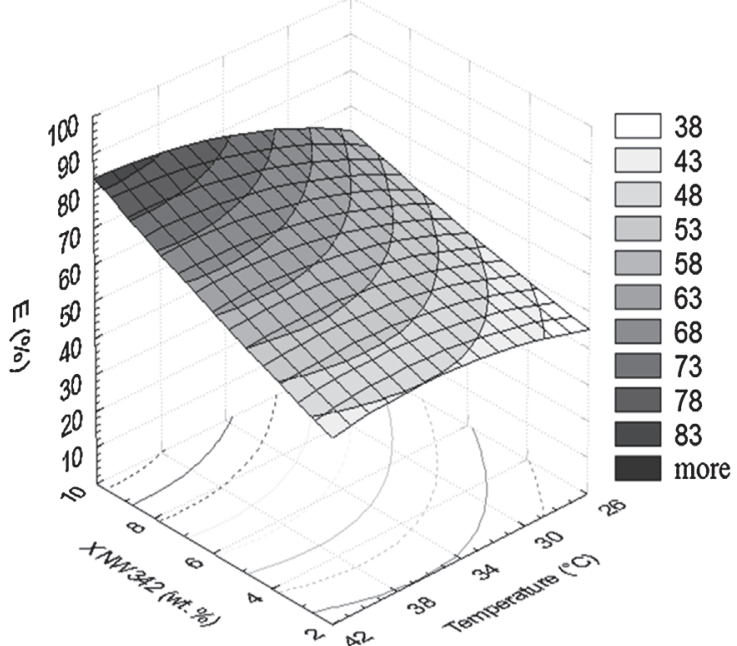

Extent of 1-phenylethanol extraction

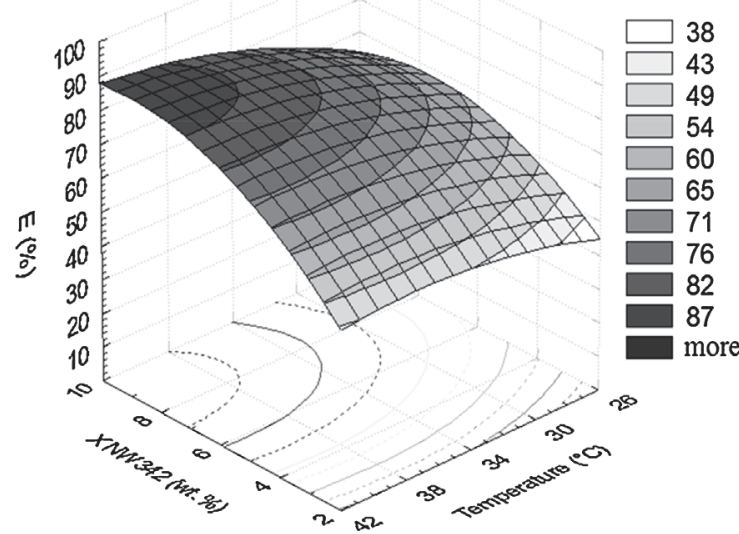

\section{Extent of phenol extraction}

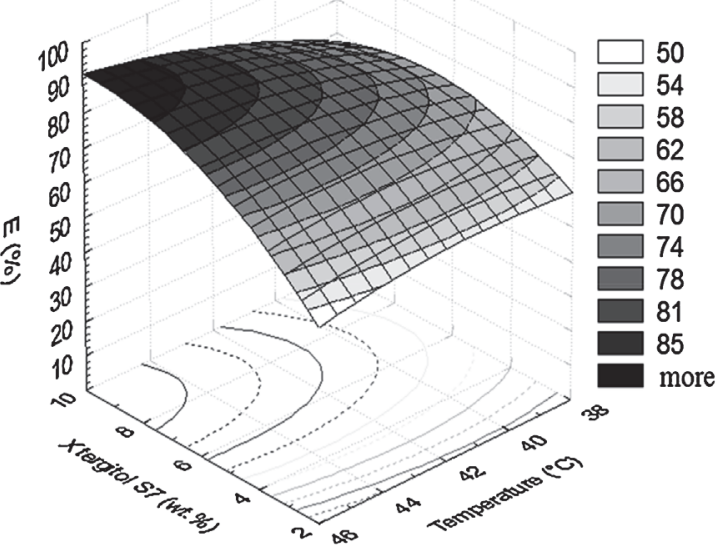

Extent of Benzyl alcohol extraction

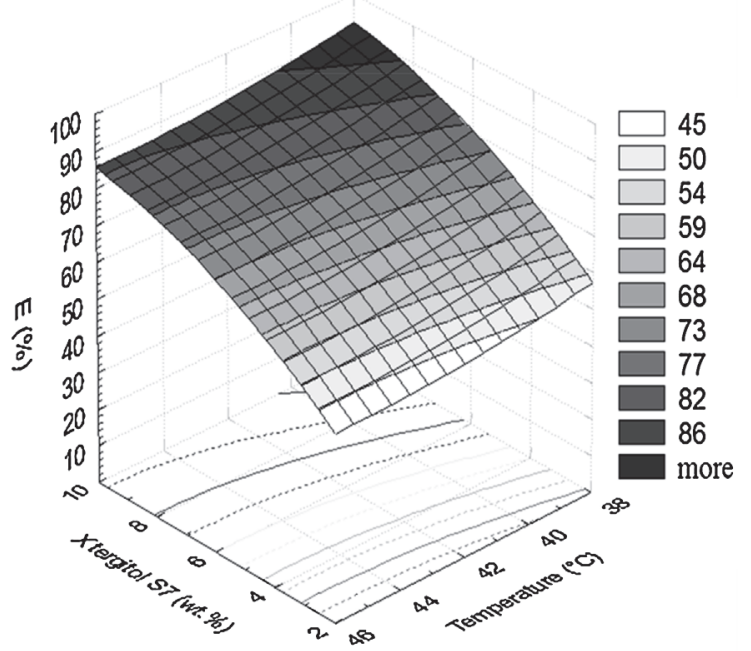

Extent of 1-phenylethanol extraction

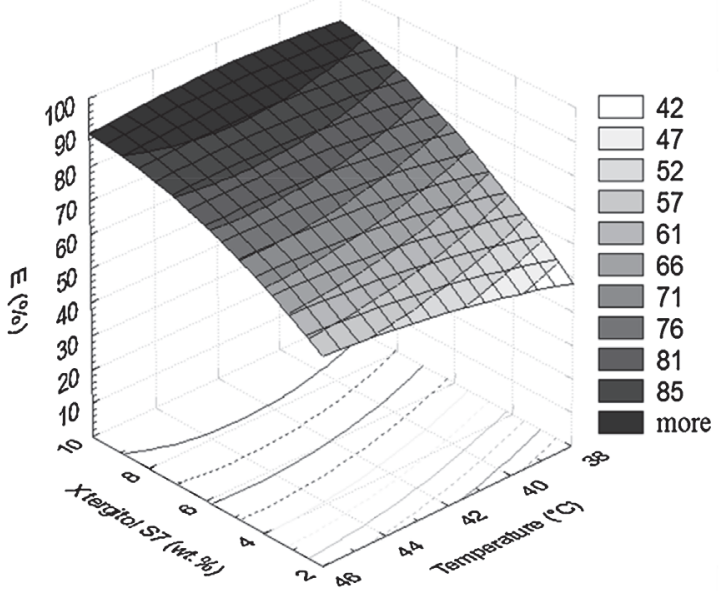

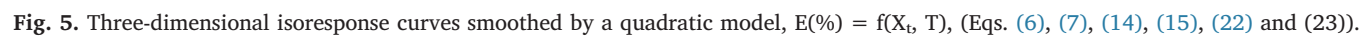

than aromatic alcohols, it may be considered as more hydrophobic and interacting more strongly, through hydrogen bonding, with ethylene oxide units. This was already noticed elsewhere $[36,64]$.

The cloud point curve lowering caused by phenol, has also been observed with other surfactants $[18,21,22]$. This phase diagram relative to a given solute can be used as a qualitative guide for the extraction process.

\subsubsection{Effect of sodium chloride}

Electrolytes can lower or raise the cloud point of nonionic surfactant systems [65]. Fig. 4 shows the decrease of the cloud point for 2 and $4 \mathrm{wt} . \%$ of each surfactant, by addition of sodium chloride. It can be 


\section{Fraction of residual phenol in the dilute phase}

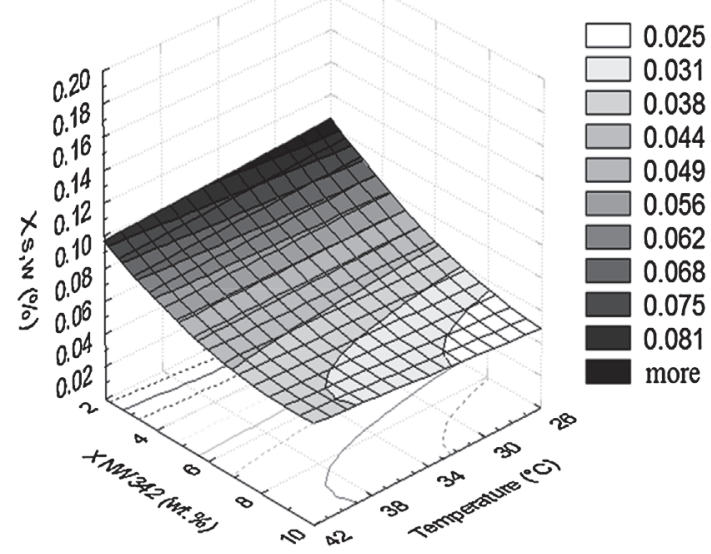

\section{Fraction of residual 1-phenylethanol} in the dilute phase

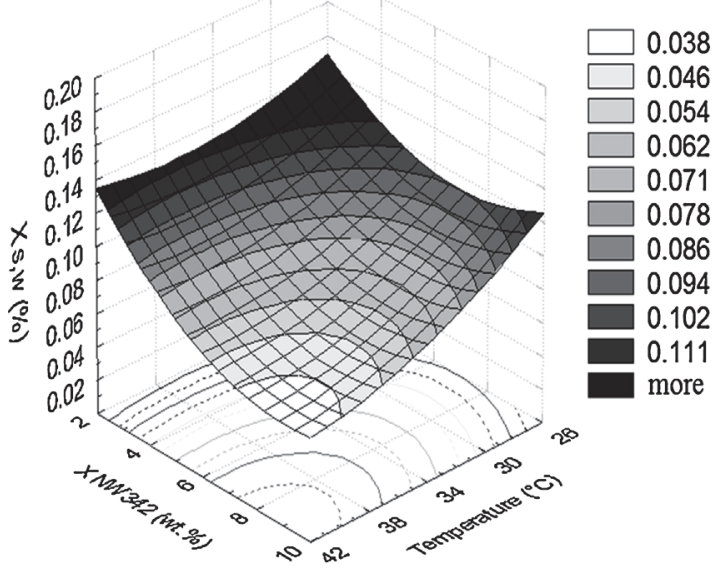

\section{Fraction of residual Benzyl alcohol in the dilute phase}

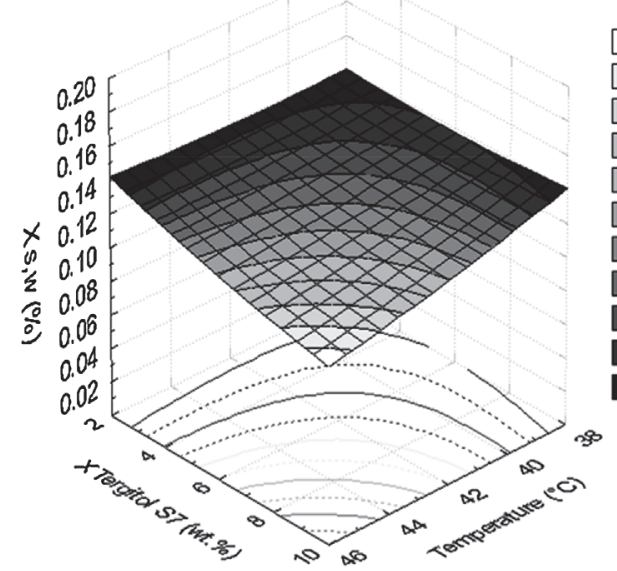

\section{Fraction of residual Benzyl alcohol} in the dilute phase

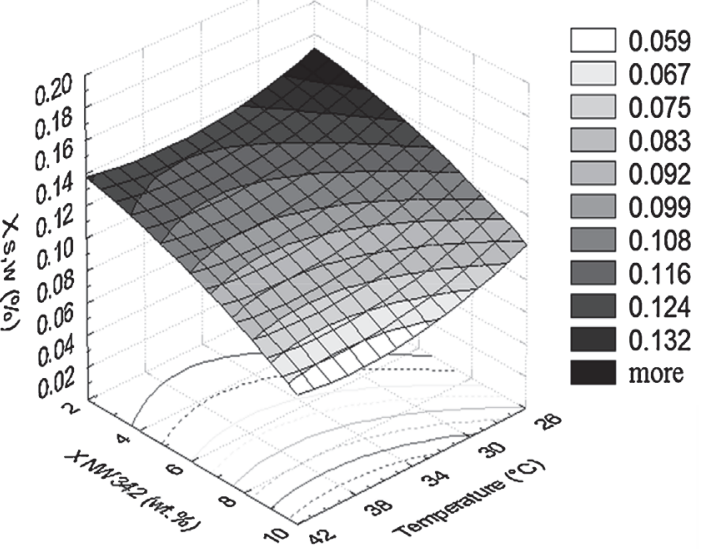

\section{Fraction of residual Phenol in the dilute phase}

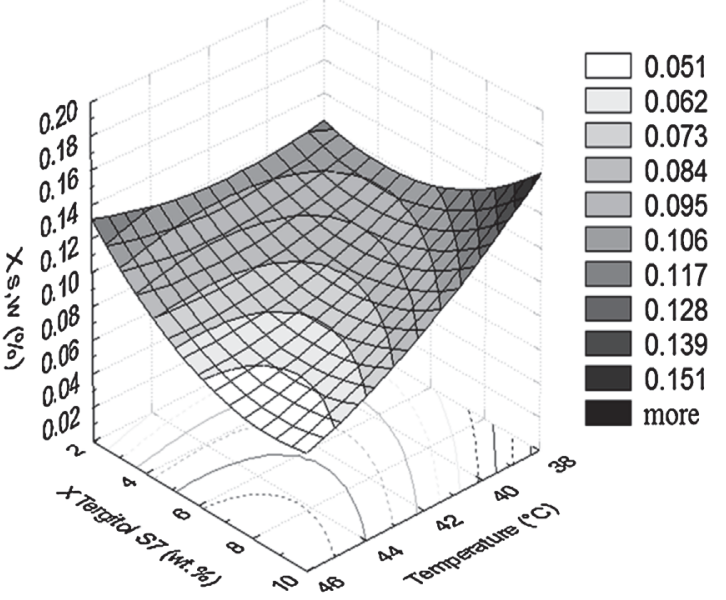

\section{Fraction of residual 1-phenylethanol in the dilute phase}
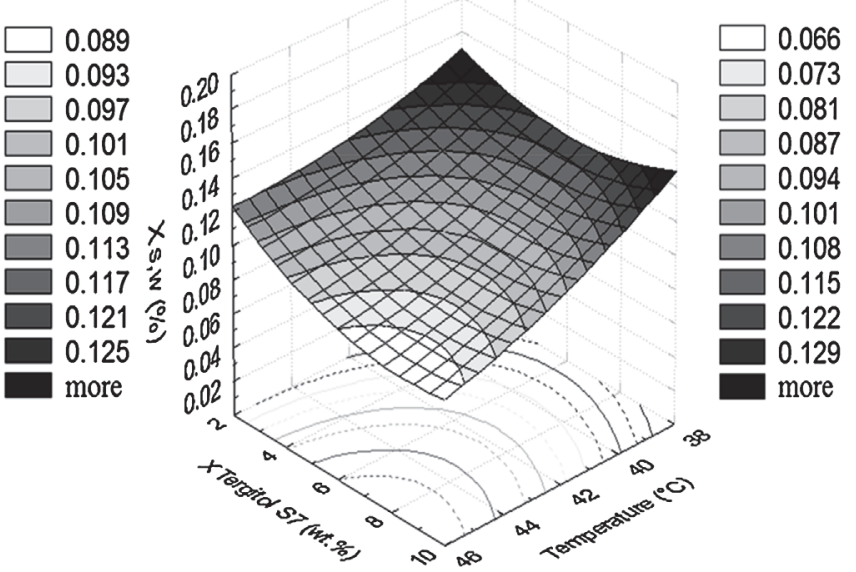

Fig. 6. Three-dimensional isoresponse curves smoothed by a quadratic model, $X_{\text {s.w }}=f\left(X_{t}, T\right)$, (Eqs. (8), (9), (16), (17), (24) and (25)).

observed that $\mathrm{NaCl}$ affects TERGITOL 15-S-7 more than SIMULSOL NW342. This phenomenon is known as the salting-out effect, caused by weakening of hydrogen bonds between the polar head groups of the nonionic surfactants and water molecules. This observation has been made with many other micellar systems [65-68]. Therefore, it is possible to adjust the cloud point at room temperature by a simple control of surfactant and salt concentrations, and consequently reduce the heating energy cost in the extraction process. Salt addition can also have an application in the extraction of heat sensitive products. 
Fraction of residual surfactant in dilute phase for phenol extraction

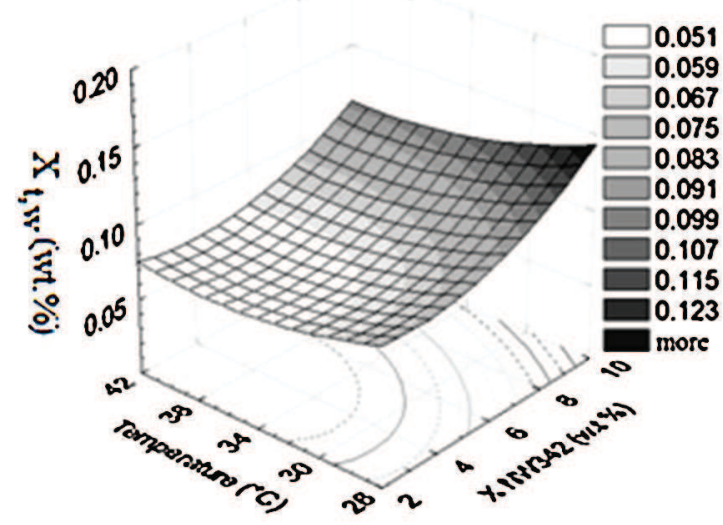

Fraction of residual surfactant in dilute phase for Benzyl alcohol extraction

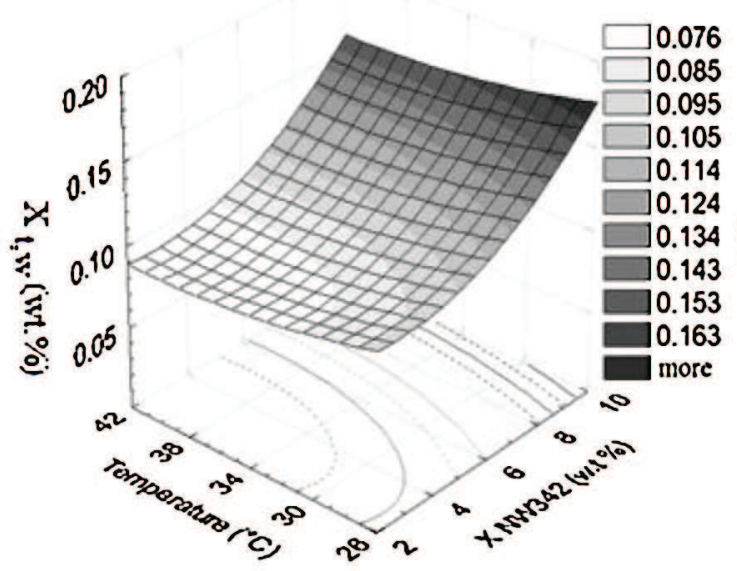

Fraction of residual surfactant in dilute phase for 1.phenylethanol extraction

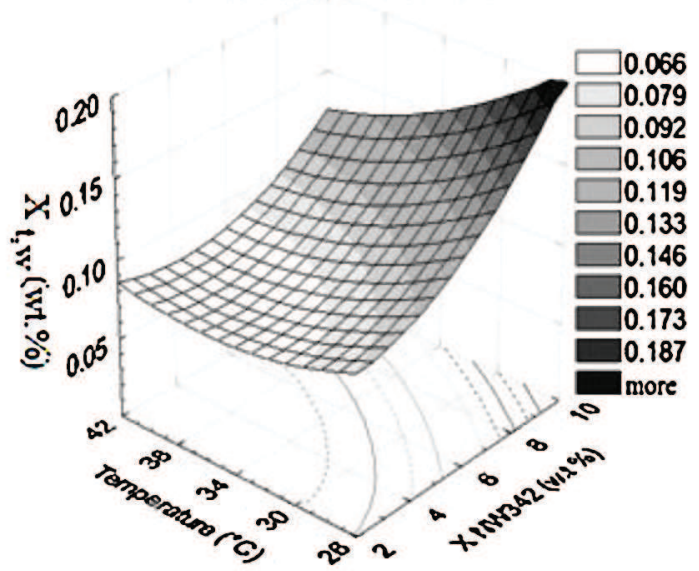

Fraction of residual surfactant in dilute phase for phenol extraction

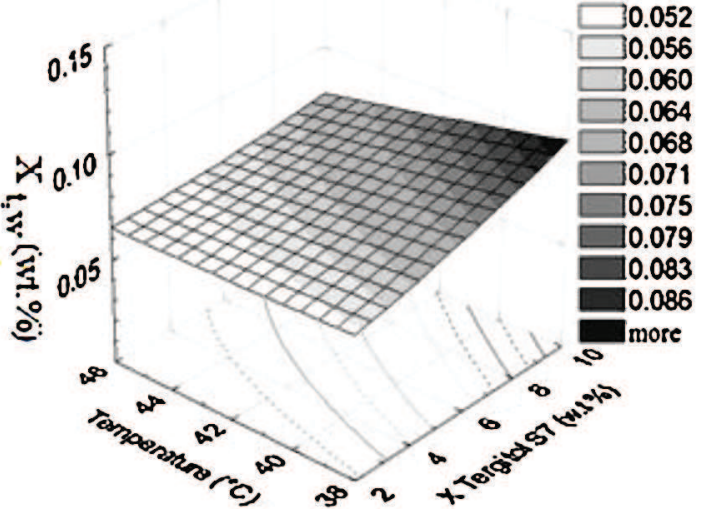

Fraction of residual surfactant in dilute phase for Benzyl alcohol extraction

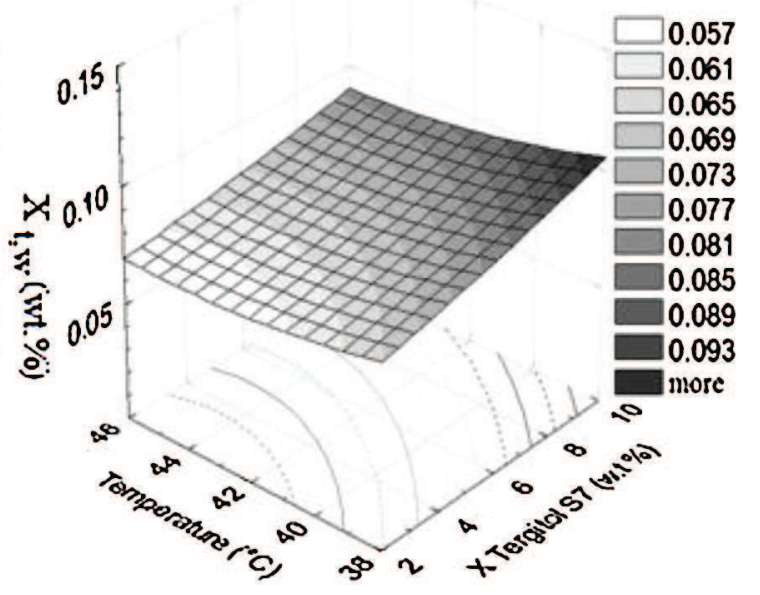

Fraction of residual surfactant in dilute phase for 1-phenylethanol extraction

Fig. 7. Three-dimensional isoresponse curves smoothed by a quadratic model, $X_{t . w}=f\left(X_{t}, T\right)$, (Eqs. (10)-(12), (19), (26) and (27)).

\subsection{Extraction results}

The CPE of 0.2 wt.\% of each solute (phenol, benzyl alcohol or 1phenylethanol) with SIMULSOL NW342 or TERGITOL 15-S-7 was performed. The results were obtained for initial surfactant concentrations, $\left(\mathrm{X}_{\mathrm{t}}\right)$ ranging from 2 to $10 \mathrm{wt} . \%$, and in temperature ranges $26-42{ }^{\circ} \mathrm{C}$ with SIMULSOL NW342 and 3-46 ${ }^{\circ} \mathrm{C}$ with TERGITOL 15-S-7.

The equations relative to the different solutes (pollutants) are: - Phenol

$\mathrm{E}_{\mathrm{NW} 342}=35.32+12.24 \mathrm{x}+0.15 \mathrm{~T}-0.11 \mathrm{xT}-0.39 \mathrm{x}^{2}+0.4410^{-2} \mathrm{~T}^{2}$ 
Volume fraction of coacervate for phenol extraction

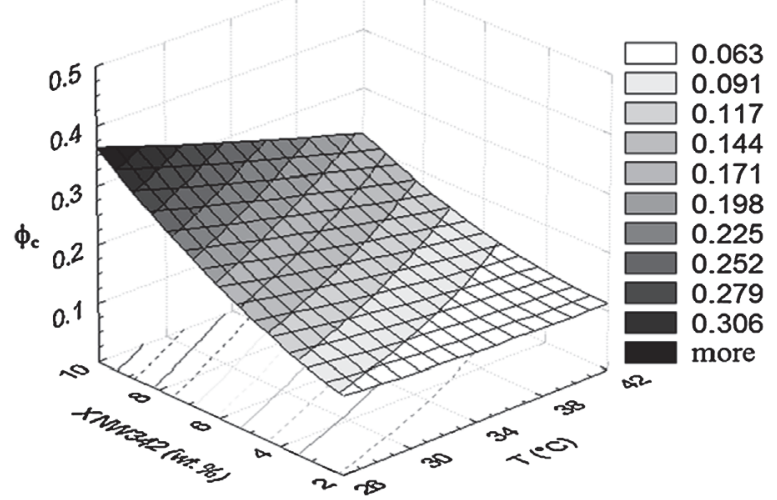

Volume fraction of coacervate for 1-phenylethanol extraction

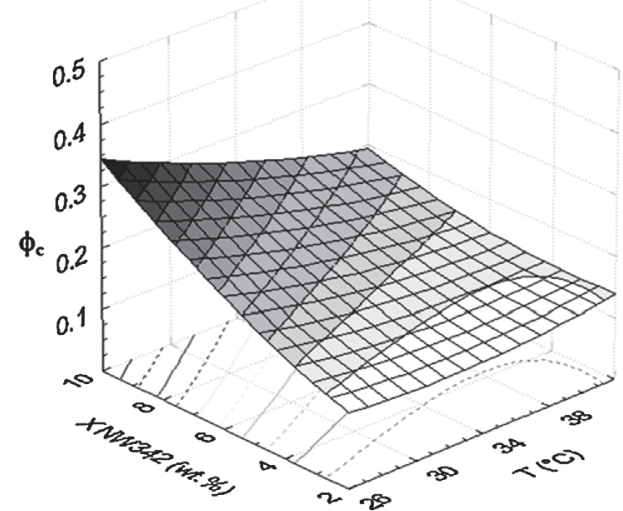

Volume fraction of coacervate
for Benzyl alcohol extraction
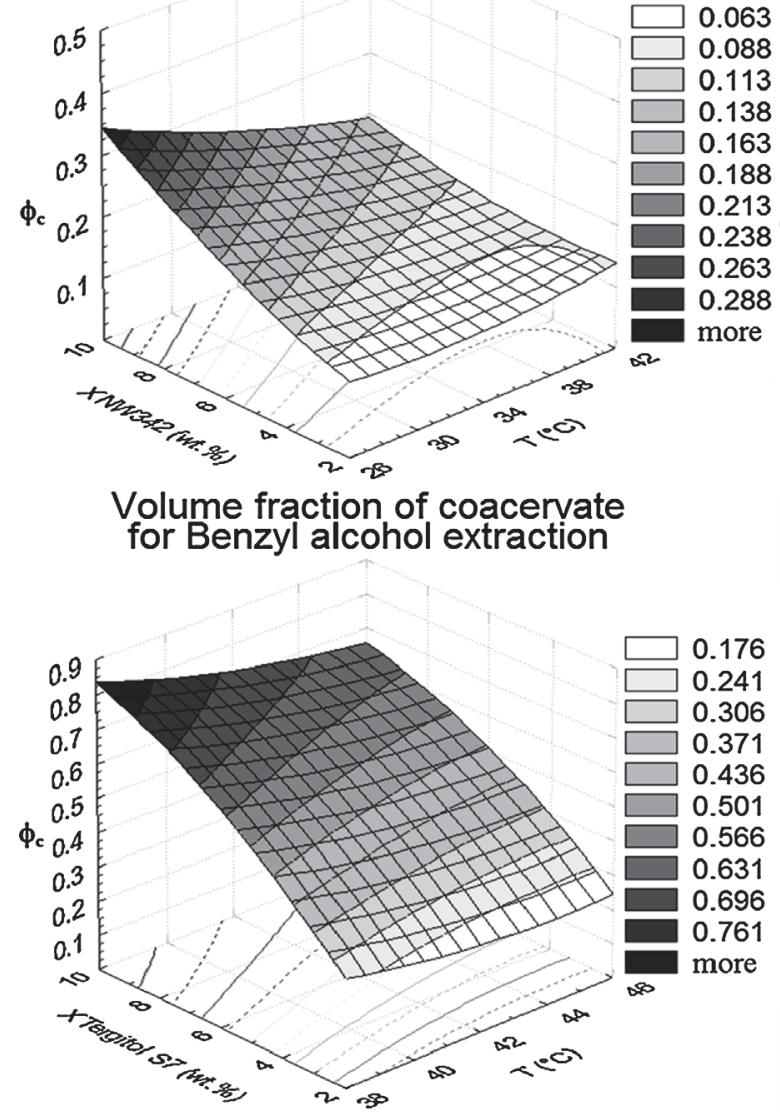

Fig. 8. Three-dimensional isoresponse curves smoothed by a quadratic model, $\phi_{c}=f\left(X_{t}, T\right)$, (Eqs. (12), (13), (20), (21), (28) and (29)).

$\mathrm{E}_{15-\mathrm{S}-7}=-292.27-10.14 \mathrm{x}+17.12 \mathrm{~T}+0.15 \mathrm{xT}-0.69 \mathrm{x}^{2}-0.22 \mathrm{~T}^{2}$

$\mathrm{X}_{\mathrm{s}, \mathrm{w}, \mathrm{NW} 342}=\left(144.49-23.89 \mathrm{x}-0.88 \mathrm{~T}+0.19 \mathrm{xT}+0.87 \mathrm{x}^{2}\right) 10^{-3}$

$\mathrm{X}_{\mathrm{S}, \mathrm{w}, 15-\mathrm{S}-7}=1.30+\left(58.42 \mathrm{x}-60.58 \mathrm{~T}-1.93 \mathrm{xT}+1.76 \mathrm{x}^{2}+0.78 \mathrm{~T}^{2}\right) 10^{-3}$

$\mathrm{X}_{\mathrm{t}, \mathrm{w}, \mathrm{NW} 342}=31.53-0.42 \mathrm{x}-1.40 \mathrm{~T}-\left(1.41 \mathrm{xT}-13 \mathrm{x}^{2}-1.91 \mathrm{~T}^{2}\right) 10^{-2}$

$\mathrm{X}_{\mathrm{t}, \mathrm{w}, 15-\mathrm{S}-7}=11.68+1.80 \mathrm{x}-0.38 \mathrm{~T}-\left(3.87 \mathrm{x} . \mathrm{T}-1.28 \mathrm{x}^{2}-0.50 \mathrm{~T}^{2}\right) 10^{-2}$
Volume fraction of coacervate for Benzyl alcohol extraction

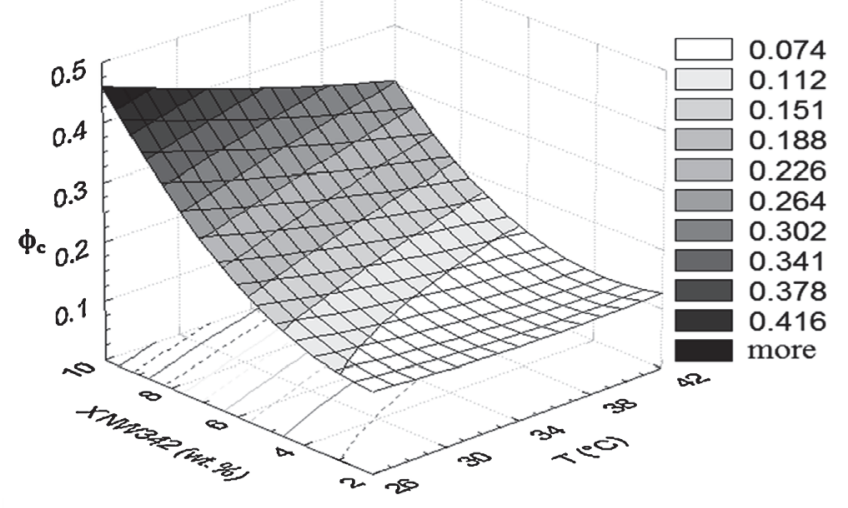

Volume fraction of coacervate for phenol extraction

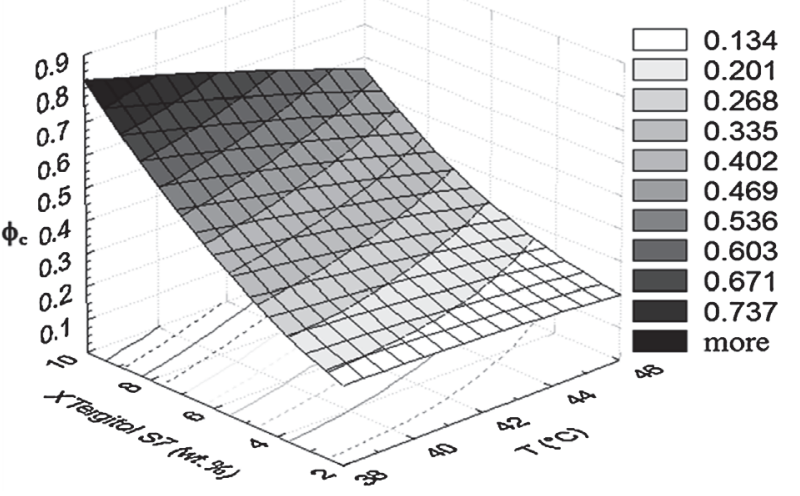

Volume fraction of coacervate for 1-phenylethanol extraction

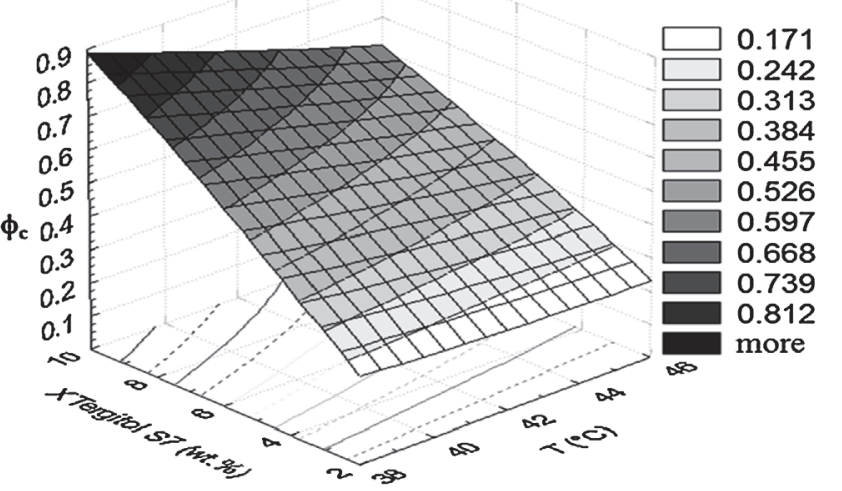

$\phi_{\mathrm{CNW} 342}=\left(94.815+40.64 \mathrm{x}-4.52 \mathrm{~T}-1.15 \mathrm{xT}+1.98 \mathrm{x}^{2}+0.08 \mathrm{~T}^{2}\right) 10^{-3}$

$\phi_{\mathrm{C} 15-\mathrm{S}-7}=-1.14+0.18 \mathrm{x}+\left(55.08 \mathrm{~T}-4.17 \mathrm{xT}+5.21 \mathrm{x}^{2}-0.62 \mathrm{~T}^{2}\right) 10^{-3}$

- Benzyl alcohol

$\mathrm{E}_{\mathrm{NW} 342}=-69.41-1.71 \mathrm{x}+6.12 \mathrm{~T}+0.13 \mathrm{xT}+0.08 \mathrm{x}^{2}-0.08 \mathrm{~T}^{2}$

$\mathrm{E}_{15-\mathrm{S}-7}=305.13+10.61 \mathrm{x}-12.46 \mathrm{~T}-0.01 \mathrm{xT}-0.41 \mathrm{x}^{2}+0.14 \mathrm{~T}^{2}$

$\mathrm{X}_{\mathrm{S}, \mathrm{w}, \mathrm{NW} 342,}=46.90+1.40 \mathrm{x}+1.10 \mathrm{~T}+0.03 \mathrm{xT}-0.08 \mathrm{x}^{2}-0.01 \mathrm{~T}^{2}$ 


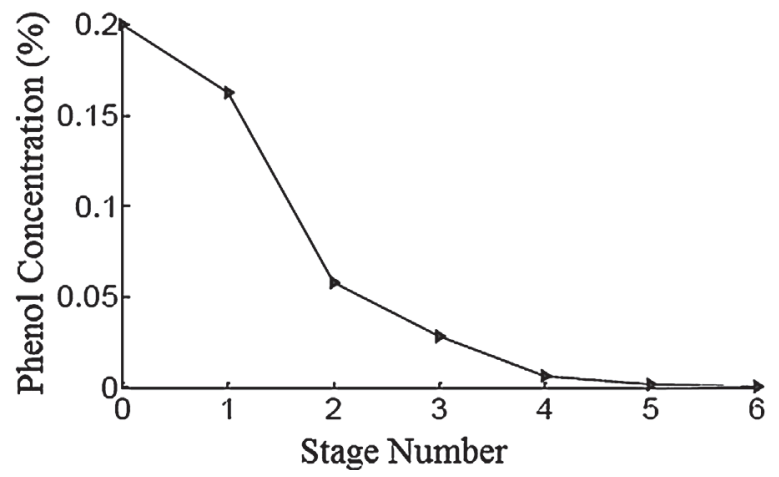

Fig. 9. Batch cross-flow extraction results after $t=135 \mathrm{~min}$.

$\mathrm{X}_{\mathrm{s}, \mathrm{w}, 15-\mathrm{S}-7}=0.31+\left(24.62 \mathrm{x}-9.82 \mathrm{~T}-0.71 \mathrm{xT}+0.21 \mathrm{x}^{2}+0.14 \mathrm{~T}^{2}\right) 10^{-3}$

$\mathrm{X}_{\mathrm{t}, \mathrm{w}, \mathrm{NW} 342}=24.75-0.87 \mathrm{x}-0.84+\left(16 \mathrm{x}^{2} \pm 1.04 \mathrm{~T}^{2}\right) 10^{-2}$

$\mathrm{X}_{\mathrm{t}, \mathrm{w}, 15-\mathrm{S}-7}=64.19+0.74 \mathrm{x}-2.71 \mathrm{~T}-\left(1.25 \mathrm{x} . \mathrm{T}-1.15 \mathrm{x}^{2}-3.09 \mathrm{~T}^{2}\right) 10^{-2}$

$\phi_{\mathrm{CNW} 342}=0.21+\left(13.53 \mathrm{x}-8.75 \mathrm{~T}-1.35 \mathrm{xT}+5.83 \mathrm{x}^{2}+0.15 \mathrm{~T}^{2}\right) 10^{-3}$

$\phi_{\mathrm{C} 15-\mathrm{S}-7}=3.51+0.21 \mathrm{x}-0.16 \mathrm{~T}-\left(0.21 \mathrm{xT}+0.44 \mathrm{x}^{2}-0.19 \mathrm{~T}^{2}\right) 10^{-2}$

- 1-Phenylethanol

$\mathrm{E}_{\mathrm{NW} 342}=-92.21+9.09 \mathrm{x}+6.26 \mathrm{~T}+0.14 \mathrm{xT}-0.83 \mathrm{x}^{2}-0.09 \mathrm{~T}^{2}$

$\mathrm{E}_{15-\mathrm{S}-7}=-369.29+21.19 \mathrm{x}+16.52 \mathrm{~T}-0.26 \mathrm{xT}-0.41 \mathrm{x}^{2}-0.17 \mathrm{~T}^{2}$

$\mathrm{X}_{\mathrm{s}, \mathrm{w}, \mathrm{NW} 342}=0.42-\left(13.24 \mathrm{x}+14.91 \mathrm{~T}+0.46 \mathrm{xT}-1.82 \mathrm{x}^{2}-0.21 \mathrm{~T}^{2}\right) 10^{-3}$

$\mathrm{X}_{\mathrm{s}, \mathrm{w}, 15-\mathrm{S}-7}=1.21+0.01 \mathrm{x}-0.05 \mathrm{~T}-\left(0.07 \mathrm{xT}-0.12 \mathrm{x}^{2}-5.40 \mathrm{~T}^{2}\right) 10^{-2}$

$\mathrm{X}_{\mathrm{t}, \mathrm{w}, \mathrm{NW} 342}=33.46+1.22 \mathrm{x}-1.59 \mathrm{~T}-\left(6.37 \mathrm{xT}-17 \mathrm{x}^{2}-2.37 \mathrm{~T}^{2}\right) 10^{-2}$

$\mathrm{X}_{\mathrm{t}, \mathrm{w}, 15-\mathrm{S}-7}=61.21+0.82 \mathrm{x}-2.59 \mathrm{~T}-\left(1.50 \mathrm{x} . \mathrm{T}-1.40 \mathrm{x}^{2}-2.96 \mathrm{~T}^{2}\right) 10^{-2}$

$\phi_{\mathrm{CNW} 342}=0.18+\left(56.47 \mathrm{x}-13.37 \mathrm{~T}-1.56 \mathrm{xT}+1.46 \mathrm{x}^{2}+0.26 \mathrm{~T}^{2}\right) 10^{-3}$

$\phi_{\mathrm{C} 15-\mathrm{S}-7}=0.46+0.28 \mathrm{x}-\left(30.17 \mathrm{~T}+4.58 \mathrm{xT}+1.25 \mathrm{x}^{2}-0.42 \mathrm{~T}^{2}\right) 10^{-3}$

\subsubsection{Extraction efficiency (E)}

The influence of surfactant concentration and temperature on the extraction percentage of organic solutes has already been studied [36]. As expected, the extraction efficiency increases with non-ionic surfactant concentration. On the other hand, an excessive increase of temperature above the cloud point can have negative effect on separation results.

According to the quadratic model (Eqs. (6), (7), (14), (15), (22) and (23)), the most favorable extraction conditions are expected within the region of higher surfactant concentration (i.e. $10 \mathrm{wt} \%$, Fig. 5). Indeed, if TERGITOL 15-S-7 is known for its high solubilization ability and extraction efficiency $[25,69,70]$, its performances are found similar to those of SIMULSOL NW342 ( $\left.\mathrm{E}_{\max } \geq 90 \%\right)$.

\subsubsection{Concentration of residual solute $\left(X_{\text {s.w }}\right)$}

The three-dimensional isoresponse curves of the studied properties fitted to the quadratic model (Eqs. (8), (69), (16), (17), (24) and (25)) are given in Fig. 6. These figures show that the percentage of residual solute in the dilute phase, $\mathrm{X}_{\mathrm{s} . \mathrm{w}}$, decreases as $\mathrm{X}_{\mathrm{t}}$ increases. On the other hand, its dependence upon tempera

ture is not monotonous, although the model gives a good illustration of experimental results. In general, a slight temperature rise has a positive effect on the extraction.

\subsubsection{Residual concentration of nonionic surfactant $\left(X_{t . w}\right)$}

Even if the nonionic surfactants used in this study are known for their good biodegradability properties and lack of ecotoxicity [71,72], the concentration of residual surfactant $\left(\mathrm{X}_{\mathrm{t} . \mathrm{w}}\right)$ still remains a very important parameter. The high loss of surfactant in the dilute phase can compromise the process reliability. Indeed, the presence of another contaminant in the dilute phase is sufficient to make the process useless. The behaviour of $\left(\mathrm{X}_{\mathrm{t} . \mathrm{w}}\right)$ according to $\mathrm{X}_{\mathrm{t}}$ and $\mathrm{T}$ is shown in Fig. 7, (fitting by the quadratic model Eqs. (10), (11), (18), (19), (26) and (27)). These figures show that the residual concentration of surfactant decreases at low surfactant concentration and rises according to temperature. The highest concentration cannot be reached with a unique surfactant concentration for the three solutes. It is equal to $10 \mathrm{wt} . \%$ and the temperatures are $26{ }^{\circ} \mathrm{C}$ and $38{ }^{\circ} \mathrm{C}$ for SIMULSOL and TERGITOL, respectively.

\subsubsection{Volume fraction of coacervate $\left(\phi_{c}\right)$}

This factor is very important to show the effectiveness of this technique. In Fig. 8 (fitting with Eqs.(12), (13), (20), (21), (28) and (29)), it is shown that a temperature rise allows to lower the volume fraction of the coacervate. It is clear that, for all solutes studied, the values and the evolution of the volume fraction of coacervate are practically the same, evidencing solutes do not affect significantly the coacervate volume, under these conditions. According to the shape of the phase diagram, the overall composition decreases when moving away from the right branch of the demixing curve. As a consequence, it is advantageous to use less surfactant in order to have a smaller coacervate volume.

\subsection{Batch cross-flow cloud point extraction}

In a batchwise preliminary study of a cross flow extraction process, a 0.2 wt.\% phenol solution was extracted in test tubes under the following conditions: $\mathrm{X}_{\mathrm{t}}=4 \%, \mathrm{t}=35^{\circ} \mathrm{C}$. With a $135 \mathrm{~min}$ contact
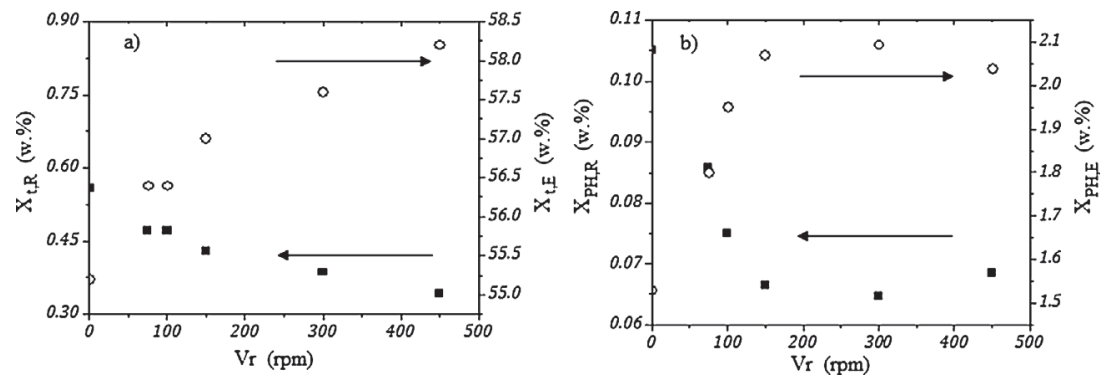

Fig. 10. Effect of stirring speed on: left: surfactant concentration in dilute phase (raffinate) and coacervate (extract); right: solute concentration in dilute phase (raffinate) and coacervate (extract); System: water $/ 4 \%$ SIMULSOL NW342/0.2\% phenol, $\mathrm{T}=35^{\circ} \mathrm{C}$. 

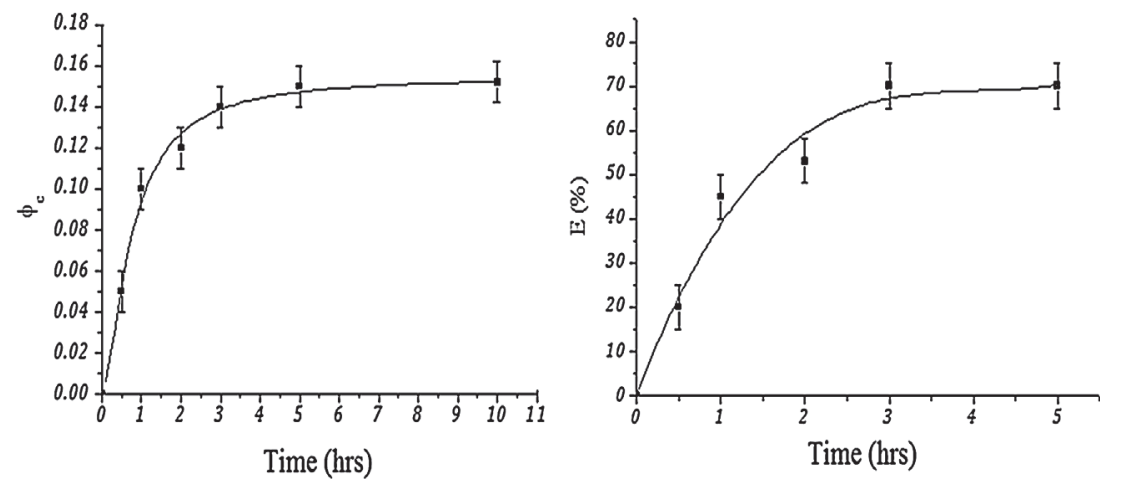

Table 2

Continuous crossflow cloud point extraction parameters.

\begin{tabular}{lllll}
\hline Input & & & Output & \\
\cline { 1 - 1 } \cline { 5 - 6 } $\mathrm{F}=19.5(\mathrm{~g} / \mathrm{min})$ & $\mathrm{S}=19.5(\mathrm{~g} / \mathrm{min})$ & & $\mathrm{E}=5.6$ & $\mathrm{R}=33.4$ \\
$\mathrm{X}_{\mathrm{PH}, \mathrm{F}}=0.078$ & $\mathrm{X}_{\mathrm{PH}, \mathrm{S}}=0$ & & $\mathrm{X}_{\mathrm{PH}, \mathrm{E}}=0.054$ & $\mathrm{X}_{\mathrm{PH}, \mathrm{R}}=0.024$ \\
$\mathrm{X}_{\mathrm{t}, \mathrm{F}}=0$ & $\mathrm{X}_{\mathrm{t}, \mathrm{S}}=1.560$ & & $\mathrm{X}_{\mathrm{t}, \mathrm{E}}=1.551$ & $\mathrm{X}_{\mathrm{t}, \mathrm{R}}=0.009$ \\
\hline
\end{tabular}

duration (equilibrium state supposedly reached, each stage corresponding to a theoretical plate), the number of extractions necessary to lower the residual phenol concentration to the allowed value is 6 (Fig. 9). In fact, at the last output, $X_{\mathrm{s}, \mathrm{w}}=0.26 \mathrm{mg} / \mathrm{L}$. For a $15 \mathrm{~min}$ contact, the number of stages rises to 9 .

\subsection{Continuous cross-flow cloud point extraction}

Fig. 10 shows that high mixing speed induces a slight increase of surfactant and solute concentration in coacervate phase. Thereby, surfactant and solute concentration decrease in the dilute phase. Indeed, good phase separation was observed with this system at $35{ }^{\circ} \mathrm{C}$. However, according to Ingram et al. [54], the increase of agitation speed greatly raises the surfactant concentration in the raffinate (dilute phase). This was also observed with our system at very high stirring speed (over $800 \mathrm{rpm}$ ) and high extraction temperatures $\left(\mathrm{T}>40{ }^{\circ} \mathrm{C}\right.$ ).

As seen previously, the cloud point extraction offers good results. However, those data were obtained after $24 \mathrm{~h}$ of settling time. Hence, for scaling-up of the CPE process, it is interesting to study the kinetics of CPE. Therefore, separation time was evaluated by following the evolution of the coacervate volume fraction $\left(\phi_{c}\right)$ and extraction extent $(E)$. The feed and solvent solutions were introduced simultaneously in the "mixer" at $\mathrm{V}_{\mathrm{r}}=300 \mathrm{rpm}$. One can notice in Fig. 11 that $\phi_{\mathrm{c}}$ increases rapidly in the early hours, then stabilizes on a plateau after about 3-4 h of settling time. The evolution of the extraction percentage shows equilibrium after $3 \mathrm{~h}$. At this time the maximum of solute was extracted. The parameters of continuous cross-flow CPE are summarized in Table 2. The volume fraction of coacervate was 0.143 . The composition of the dilute phase (raffinate) was $0.070 \%$ phenol and $0.028 \%$ SIMULSOL NW342, the composition of coacervate phase (extract) was $0.93 \%$ phenol and $27.4 \%$ SIMULSOL NW342. Let us remember that at equilibrium (as determined in test tube), the extraction percentage

$N=\frac{\log \left(\frac{X_{f}}{X_{n}}\right)}{\log \left(\frac{K S}{F+1}\right)}$

\section{Conclusion}

Fig. 11. Extraction parameters of the system: water/4\% SIMULSOL NW342/0.2\% phenol at $30{ }^{\circ} \mathrm{C}$; a) Volume fraction of coacervate $\left(\phi_{\mathrm{c}}\right)$; b) Extraction efficiency (E).

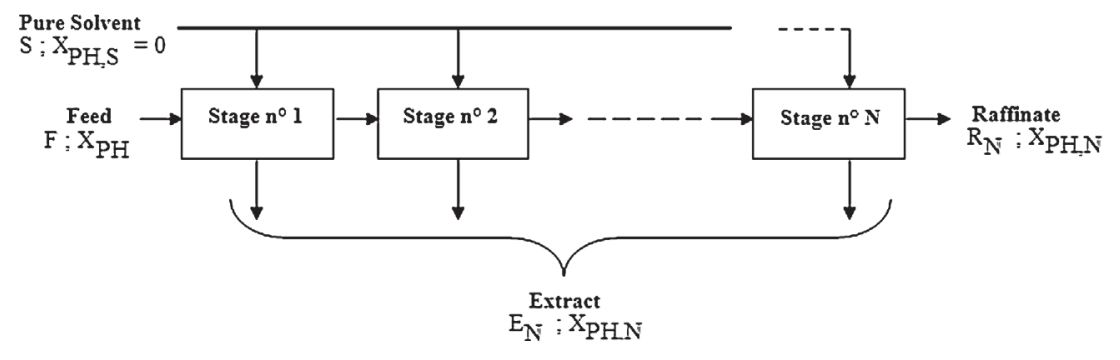

reached $73 \%$, while, using the mixer-settler, a value of $69 \%$ was obtained. This result agrees with the hypothesis that a mixer-settler stage may be considered as a theoretical stage.

For a multi-stage contact with thermostatic pilot implemented previously, all stages were operated at the same temperature $\left(30{ }^{\circ} \mathrm{C}\right)$ for the system water/4 wt.\% SIMULSOL NW342/0.2\% phenol. After the first stage contact, the raffinate phase was contacted with a new solvent quantity (Fig. 12).

The cross-flow stage number $\mathrm{N}$ needed to achieve a specified raffinate composition, $\mathrm{X}_{\mathrm{n}}$, is given by the following formula:

The partition coefficient $\mathrm{K}=4.7$ and extraction solvent ratio $(\mathrm{S} / \mathrm{F})$ are kept constant. Upon seeing the first three stages results, it was assumed that the remaining stages would show the same behaviour ( $\mathrm{E} \approx 69 \%$ ). Those results allowed us to estimate the mass balance of each stage. Thereby, the stage number which allows less than $0.3 \mathrm{ppm}$ of phenol in raffinate, was equal to 6 (Fig. 13).

Coacervate regeneration for surfactant reuse, by $\mathrm{pH}$ changes and salt precipitation, has been addressed and operated successfully with very similar systems $[21,36]$.

Cloud point extraction (CPE) with nonionic surfactants has become a very attractive separation technique in recent years. The objective of this study was to develop a simple, practical CPE with selected biodegradable commercial nonionic surfactants. Two alkoxylated species, SIMULSOL NW342 and TERGITOL 15-S-7 were chosen to extract phenol, benzyl alcohol and 1-phenylethanol. Those organic solutes lower the surfactant cloud points, phenol showing the strongest effect. A reduced number of experiments, thanks to a central composite design, gives an insight on the trends followed by the extraction percentage, the residual solute and surfactant concentrations in the dilute phase, and the coacervate volume fraction, but the choice of the optimal conditions requires a compromise between all these parameters. An in-depth analysis of the isoresponse surfaces leads us to recommend: $\mathrm{X}_{\mathrm{NW} 342} \approx 4-6 \mathrm{wt} . \% ; \quad 30^{\circ} \mathrm{C}<\mathrm{T}<35^{\circ} \mathrm{C}$, and $\mathrm{X}_{15-\mathrm{S}-7} \approx 4-6 \mathrm{wt} . \%$;

Fig. 12. Cross-flow extraction process for $\mathrm{N}$ stages. 

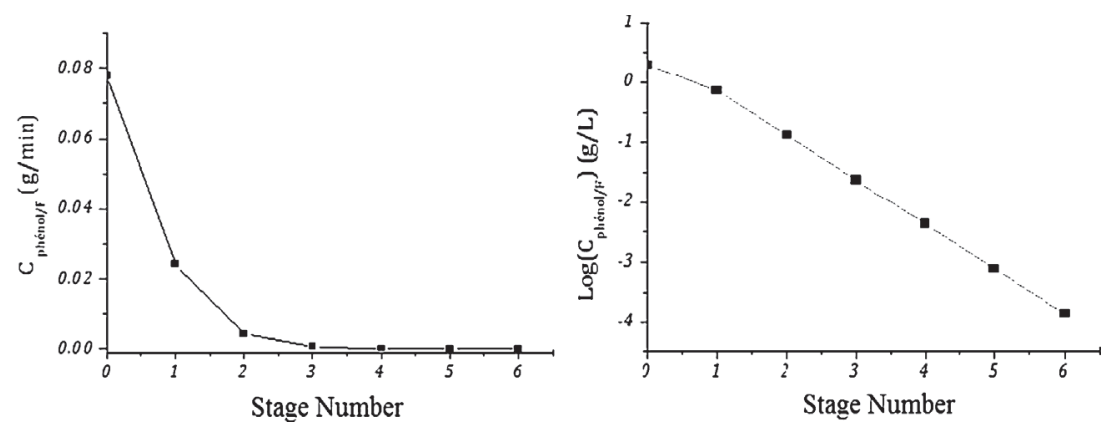

Fig. 13. Stage number for continuous cross-flow extraction for the system: 4 wt. $\%$ SIMULSOL NW342/0,2\% phenol at $30{ }^{\circ} \mathrm{C}$ in the mixersettler.
$40{ }^{\circ} \mathrm{C}<\mathrm{T}<44{ }^{\circ} \mathrm{C}$, as the most favorable initial surfactant concentration and temperature ranges. A batch cross flow CPE experiment with SIMULSOL NW342 and phenol yielded encouraging results. Therefore, a continuous cross flow CPE was developed and showed that the allowed residual pollutant concentration could be reached after 6 stages. Our results thus show that SIMULSOL NW342 can be chosen in a first approach of a multistage crossflow CPE process.

\section{References}

[1] S.J. Kulkarni, J.P. Kaware, Review on research for removal of phenol from wastewater, Int. J. Sci. Res. Publ. 3 (4) (2013) 1-5.

[2] G. Moussavi, M. Mahmoudi, B. Barikbin, Biological removal of phenol from strongwastewaters using a novel MSBR, Water Res. 43 (5) (2009) 1295-1302.

[3] A. Rubalcaba, M.E. Suarez-Ojeda, J. Carrera, J. Font, F. Stüber, C. Bengoa, A. Fortuny, A. Fabregat, Biodegradability enhancement of phenolic compounds by hydrogen peroxidepromoted catalytic wet air oxidation, Catal. Today 124 (3-4) (2007) 191-197.

[4] M. Ehtash, M.C. Fournier-Salaün, K. Dimitrov, P. Salaün, A. Saboni, Phenol removal from aqueous media by pertraction using vegetable oil as a liquid membrane, Environ. Chem. Eng. 250 (2014) 42-47.

[5] D. Sannadurgappa, N.H. Ravindranath, R.H. Aladakatti, Toxicity bioaccumulation and metabolism of phenol in the freshwater fish Oreochromismossambicus, J. Basic Clin. Physiol. Pharmacol. 18 (1) (2007) 65-77.

[6] Toxicological Profile for Phenol, September 2008. US Public Health Service, Agency for Toxic Substances and Disease Registry, 2008 www.atsdr.cdc.gov/toxprofiles tp115-c1.pdf (updated December 15, 2008).

[7] Decree no. 2006-665 (June 7, 2006) - art. 19 (V) JORF (June 8, 2006), modifiedbyArrêté 2006-08-06 art.1, JORF, October 16, 2007

[8] W. Kujawski, A. Warszawski, W. Ratajczak, T. Poręski, W. Capała, I. Ostrowska, Removal of phenol from wastewater by different separation techniques, Desalination 163 (1-3) (2004) 287-296.

[9] H. Yamasaki, Y. Makihata, K. Fukunaga, Efficient phenol removal of wastewater from phenolic resin plants using crosslinked cyclodextrin particles, J. Chem. Technol. Biotechnol. 81 (7) (2006) 1271-1276.

[10] C. Andriantsiferana, C. Julcour-Lebigue, C. Creanga-Manole, H. Delmas, A.M. Wilhelm, Competitive adsorption of p-hydroxybenzoic acid and phenol on activated carbon: experimental study and modeling, J. Environ. Eng. 139 (3) (2013) 402-409.

[11] M. Shanthi, E. Ginish, D. Rajamanickam, Photocatalytic degradation of an organic pollutant, benzyl alcohol using an enhanced solar Photo-Fenton process, Int. J. ChemTech Res. 5 (5) (2013) 2521-2533.

[12] S. Paavola, K. Zetterberg, T. Privalov, I. Csöregh, C. Moberg, Aerobic oxidationof 1Phenylethanol catalyzed by palladaheterocycles, Adv. Synth. Catal. 346 (2004) 237-244.

[13] G. Tchobanoglous, F.L. Burton, H. David Stensel, Wastewater Engineering Treatment and Reuse, 4th ed., Metcalf \& Eddy, Inc., McGraw-Hill Education, 2003.

[14] V. Degiorgio, Physics of amphiphiles: micelles, vesicles and microemulsions, in: M. Corti, V. Degiorgio (Eds.), Proceedings of the International School of Physics, Enrico Fermi, Course Xc, North Holland, Amsterdam, 1983, pp. 303-335.

[15] H. Watanabe, H. Tanaka, A non-ionic surfactant as a new solvent for liquid-liquid extraction of zinc (II) with 1-(2-pyridylazo)-2-naphthol, Talanta 25 (1978) 585-589.

[16] J.F. Scamehorn, J.H. Harwell, Surfactant-Based treatment of aqueous process stream, in: Surfactant in Chemical/Process Engineering, D.T. Wasan, M.E. Ginn, D.O. Shah (Eds.), Surfactant Science Series, 28 Marcel Dekker, New York, 1988, pp. 77-125.

[17] N.D. Gullickson, J.F. Scamehorn, J.H. Harwell, Liquid-coacervate extraction, in: Surfactant-based Separation Processes, J.F. Scamehorn, J.H. Harwell (Eds.), Surfactant Science Series, 33 Marcel Dekker, New York, 1989, pp. 141-152.

[18] S. Akita, H. Takeuchi, Cloud Point extraction of organic compounds from aqueous solution with non-ionic surfactant, Sep. Sci. Technol. 30 (1995) 833-846.

[19] W.L. Hinze, E. Pramauro, A critical review of surfactant-mediated phase separation (Cloud Point Extraction): theory and application, Crit. Rev. Anal. Chem. 24 (2) (1993) 133-177.

[20] F.H. Quina, W.L. Hinze, Surfactant-mediated cloud point extraction: an environmentally benign alternative separation approach, Ind. Eng. Chem. Res. 38 (1999) 150-168.

[21] E.L. De Barros Neto, Extraction Liquide-liquide à Deux Phases Aqueuses: Systèmes Phénol/Tensioactif Polyéthoxylés. Thesis, Institut National Polytechnique, Toulouse, 1999.

[22] E.L. De Barros Neto, J.P. Canselier, C. Gourdon, Organic solvent-free extraction of phenol through liquid-coacervate systems, Solvent Extraction for the 21 st Century, Society of Chemical Industry, London, in: M. Cox, M. Hidalgo, M. Valiente (Eds.), Proceedings of the International Solvent Extraction Conference, Barcelone (ISEC'99), July 1999, 1 2001, pp. 171-176.

[23] S. Sakulwongyai, P. Trakultamupatam, J.F. Scamehorn, S. Osuwan, S.D. Christian, Use of surfactant coacervate phase to extract chlorinated aliphatic compounds from water: extraction of chlorinated ethanes and quantitative comparison to solubilization in micelles, Langmuir 16 (2000) 8226-8230.

[24] W. Kimchuwanit, S. Osuwan, J.F. Scamehorn, J.H. Harwell, K.J. Haller, Use of a micellar-rich phase coacervate to extract trichlorethylene from water, Sep. Sci. Technol. 35 (13) (2000) 1991-2002.

[25] D.S. Bai, J.L. Li, S.B. Chen, B.H. Chen, A novel cloud-point extraction process for preconcentrating selected polycyclic aromatic hydrocarbons in aqueous solutions, Environ. Sci. Technol. 35 (2001) 3936-3940.

[26] K. Materna, I. Milosz, I. Miesiac, G. Cote, J. Szymanowski, Removal of phenols from aqueous streams by the cloud point extraction technique with oxyethylated methyl dodecanoates as surfactants, Environ. Sci. Technol. 35 (2001) 2341-2346.

[27] K. Materna, J. Szymanowski, Separation of phenols from aqueous micellar solutions by cloud point extraction, J. Colloid Interface Sci. 255 (2002) 195-201.

[28] J. Li, B. Chen, Equilibrium partition of polycyclic aromatic hydrocarbons in a cloudpoint extraction process, Colloid Polym. Sci. 263 (2003) 625-632.

[29] R. Carabias-Martinez, J. Rodriguez-Ganzal, C. Dominguez-Alvarez, J.P. GarciaMendez, Prediction of the behavior of organic pollutants using cloud point extraction, J. Chromatogr. A 1005 (2003) 23-34.

[30] Z.S. Ferrera, C.P. Sanz, C.M. Santana, J.J.S. Rodriguez, The use of micellar systems in the extraction and pre-concentration of organic pollutants in environmental samples, Trends Anal. Chem. 23 (7) (2004) 479-489.

[31] M.K. Purkait, S. Vijay, S. Dasgupta, S. De, Separation of Congo red by surfactant mediated cloud point extraction, Dyes Pigm. 63 (2) (2004) 151-159.

[32] M.K. Purkait, S. Banerjee, S. Mewara, S. Dasgupta, S. De, Cloud point extraction of toxic Eosin dye using Triton X-100 as nonionic surfactant, Water Res. 39 (2005) 3885-3890.

[33] M.K. Purkait, S. Dasgupta, S. De, Performance of TX-100 and TX-114 for the separation of chrysoidine dye using cloud point extraction, J. Hazard. Mater 137 (2006) 827-835.

[34] S. Xie, M.C. Paau, C.F. Li, D. Xiao, M.M.F. Choi, Separation and preconcentration of persistent organic pollutants by cloud point extraction, J. Chromatogr. A 1217 (16) (2010) 2306-2317.

[35] S. Ameur, B. Haddou, Z. Derriche, J.P. Canselier, C. Gourdon, Cloud point extraction of (9-tetrahydrocannabinol from cannabis resin, Anal. Bioanal. Chem. 405 (2013) 3117-3123.

[36] B. Haddou, J.P. Canselier, C. Gourdon, Use of cloud point extraction with ethoxylated surfactants for organic pollution removal, in: M. Fanun (Ed.), The Role of Colloidal Systems in Environmental Protection, Elsevier, 2014, 2017, pp. 97-142.

[37] Z. Talbi, B. Haddou, H. Ghouas, M. Kameche, Z. Derriche, C. Gourdon, Cationic dye removal from aqueous solutions using ionic liquid and nonionic surfactant-ionic liquid systems: a comparative study based upon experimental design, Chem. Eng. Commun. 201 (1) (2014) 41-52.

[38] H. Ghouas, B. Haddou, M. Kameche, L. Louhibi, Z. Derriche, J.P. Canselier, C. Gourdon, Cloud point extraction of $\alpha$-amino acids, Sep. Sci. Technol. 49 (14) (2014) 2142-2150.

[39] H. Ghouas, B. Haddou, M. Kameche, J.P. Canselier, C. Gourdon, Removal of tannic acid from aqueous solution by cloud point extraction and investigation of surfactant regeneration by microemulsion extraction, J. Surf. Deterg. 19 (1) (2016) 57-66.

[40] S. Habbal, B. Haddou, M. Kameche, Z. Derriche, J.P. Canselier, C. Gourdon, Cloud point or ionic liquid extraction of furfural from aqueous solution: acomparative study based upon experimental design, Desalin. Water Treat. 57 (50) (2016) 23770-23778.

[41] A. Favre-Réguillon, M. Draye, G. Lebuzit, S. Thomas, J. Foos, G. Cote, A. Guy, Cloud point extraction: an alternative to traditional liquid?liquid extraction for lanthanides (III) separation, Talanta 63 (2004) 803-806.

[42] M. Ghaedi, M. Niknam, K. Niknam, E.M. Soylak, Application of cloud point extraction for copper, nickel, zinc and iron ions in environmental samples, J. Chin. 
Chem. Soc. 56 (5) (2009) 981-986.

[43] T. Madrakian, F. Ghazizadeh, Cloud-point preconcentration and spectrophotometric determination of trace amounts of molybdenum (VI) in steels and water samples, J. Hazard. Mater 153 (2008) 695-700.

[44] M. De Almeida Bezerra, M.A. ZezziArruda, S.L. Costa Ferreira, Cloud point extraction as a procedure of separation and pre-concentration for metal determination using spectroanalytical techniques: a review, Appl. Spectrosc. Rev. 40 (5) (2005) 269-299.

[45] E.K. Paleologos, A.G. Vlessidis, M.I. Karayannis, N.P. Evmiridis, On-line sorptionpreconcentration of metals based on mixed micelle cloud point extraction prior to theirdetermination with micellar chemiluminescence: application to the determination of chromium at ng $1^{-1}$ levels, Anal. Chim. Acta 477 (2) (2003) 223-231.

[46] E.K. Paleologos, D.L. Giokas, M.I. Karayannis, Micelle-mediated separation and cloud point extraction, Trends Anal. Chem. 24 (5) (2005) 426-436.

[47] L.J.N. Duarte, Extraction à Deux Phases Aqueuses à l'aide d'alcools Polyéthoxylés En Vue De l'éliminationde Polluants Organiques Et d'ions métalliques. Thesis, Institut National Polytechnique, Toulouse, 2005.

[48] J.P. Canselier, C. Gourdon, L.J.N. Duarte, E.L. De Barros Neto, B. Haddou, C. Gumila, Procédé d'extraction sans solvant des polluants organiques et métalliques. French Patent FR2900145 (A1); WO-2007-122158 (PCT/EP2007/053777), April 18, 2007.

[49] L.J.N. Duarte, J.P. Canselier, Two-aqueous phase extraction for the removal of organic pollutants ant metalions, CHEMPOR 2008-10th International Chemical and Biological Engineering Conference, Braga (Portugal) 4-8 September, 2008 (Proceedings on disk).

[50] P. Trakultamupatam, J.F. Scamehorn, S. Osuwan, Scaling up cloud point extraction of aromatic contaminants from wastewater in a continuous rotating disk contactor. I. Effect of Disk Rotation Speed and Wastewater to Surfactant Ratio, Sep. Sci. Technol. 39 (3) (2004) 479-499.

[51] P. Trakultamupatam, J.F. Scamehorn, S. Osuwan, Scaling up cloud point extraction of aromatic contaminants from wastewater in a continuous rotating disk contactor. II. Effect of operating temperature and added electrolyte, Sep. Sci. Technol. 39 (3) (2004) 501-516.

[52] P. Taechangam, J.F. Scamehorn, S. Osuwan, T. Rirksomboon, Continuous cloud point extraction of volatile organic contaminants from wastewater in a multi-stage rotating disc contactor: effect of structure and concentration of solutes, Sep. Sci. Technol. 43 (14) (2008) 3601.

[53] B. Yao, L. Yang, Pilot-scale ultrasonic assisted cloud point extraction of polycyclic aromatic hydrocarbons from polluted water, Sep. Sci. Technol. 43 (6) (2008) $1564-1580$.

[54] T. Ingram, S. Storm, P. Glembin, S. Bendt, D. Huber, T. Mehling, I. Smirnova, Aqueous surfactant two-phase systems for the continuous countercurrent cloud point extraction, Chem. Ing. Techn. 84 (6) (2012) 840-848.

[55] F.A. Carey, Advanced Organic Chemistry, 3rd ed., Plenum, New York, 1990.

[56] H.H. Philip, M.M. William, Handbook of Physical Properties of Organic Chemicals,
Lewis Publishers, New York, 1997.

[57] http://www.chemicalbook.com/chemicalproductproperty_en_cb0744841.htm, 2017

[58] J. Sangster, Octanol - water partition coefficients of simple organic compounds, J. Phys. Chem. Ref. Data 18 (3) (1989) 1111-1227.

[59] G.R. Bear, Universal Detection and Quantitation of Surfactant by High-performance liquid chromatography by means of the evaporative light-scattering detector, J. Chromatogr. 459 (1988) 91-107.

[60] Y. Mengerink, H.C.J. de Man, W.S. Vander, Use of an evaporative light scattering detector in reversed phase high-performance liquid chromatography of oligomeric surfactants, J. Chromatogr. 552 (1991) 593-604.

[61] W. Miszkiewicz, J. Szymanowski, Analysis of non-ionic surfactant with polyoxyethylene chains by high-performance liquid chromatography, Critical Rev. Anal. Chem. 25 (4) (1996) 203-246.

[62] G.E.P. Box, Empirical Model Building and Response Surfaces, John Wiley \& Sons, New York, 1987.

[63] G. Sado, M.C. Sado, Les plans d'Expériences: de l'Expérimentation à l'Assurance qualité, AFNOR (1991) 125-145.

[64] L.J.N. Duarte, J.P. Canselier, Oxo-alcohol ethoxylates: surface and thermodynamic properties and effect of various additives on the cloud point, Tenside Surf. Deterg. 42 (5) (2005) 299-306.

[65] H. Schott, A.E. Royce, S.K. Han, Effect of inorganic additives on solutions of nonionic surfactants. VII, cloud point shift values of individual ions, J. Colloid Interface Sci. 98 (1) (1984) 196-201.

[66] K.S. Sharma, S.R. Patil, A.K. Rakshit, Study of the cloud point of $\mathrm{C}_{12} \mathrm{E}_{\mathrm{n}}$ nonionic surfactants: effectof additives, Colloids Surf. A: Physicochem. Eng. Aspects 219 (2003) 67-74.

[67] K. Weckström, A.C. Papageorgiou, Lower consolute boundaries of the nonionic surfactant $\mathrm{C}_{8} \mathrm{E}_{5}$ in aqueous alkali halide solutions: an approach to reproduce the effects of alkali halideson the cloud-point temperature, J. Colloid Interface Sci. 310 (2007) 151-162.

[68] M.S. Alam, A.M. Siddiq, N. Kamely, M. Priyadharshini, V. Mythili, A.B. Mandal, Influence of additives on clouding of non-ionic surfactant triton X-114 solutions: evaluation of thermodynamics at CP, J. Disp. Sci. Technol. 36 (11) (2015) 1569-1576.

[69] B.H. Chen, C.A. Miller, P.R. Garrett, Rates of solubilization of triolein into nonionic surfactant solutions, Colloids Surf. A 128 (1997) 129-143.

[70] J.L. Li, B.H. Chen, Solubilization of model polycyclic aromatic hydrocarbons by nonionic surfactants, Chem. Eng. Sci. 57 (2002) 2825-2835.

[71] A. Szymanski, B. Wyrwas, E. Bubien, T. Kurosz, W. Hreczuch, W. Zembrzuski, Z. Lukaszewski, Biodegradation of oxo-alcohol ethoxylates in the continuous flow activated sludge simulation test, Water Res. 36 (13) (2002) 3378-3386.

[72] C.G. Naylor, J. Frank, F.J. Castaldi, B.J. Hayes, Biodegradation of nonionic surfactants containing propylene oxide, J. Am. Oil Chem. Soc. 65 (10) (1988) 1669-1676. 